\title{
Terms of Trade and Global Efficiency Effects of Free Trade Agreements, 1990-2002 *†
}

\author{
James E. Anderson \\ Boston College \\ NBER
}

\author{
Yoto V. Yotov \\ Drexel University
}

October 11, 2011

\begin{abstract}
This paper infers the terms of trade effects of the Free Trade Agreements (FTAs) of the 1990s. Using panel data methods to resolve two way causality between trade and FTAs, we estimate large FTA effects on bilateral trade volume in 2 digit manufacturing goods from 1990-2002. We deduce the terms of trade changes implied by these volume effects for 40 countries plus a rest-of-the-world aggregate using the structural gravity model. Some countries gain over $10 \%$, some lose less than $0.2 \%$. Overall, using a novel measure of the change in iceberg melting, global efficiency rises $0.62 \%$.
\end{abstract}

JEL Classification Codes: F13, F14, F16

Keywords: Free Trade Agreements, Gravity, Terms of Trade, Coefficient of Resource Utilization.

${ }^{*}$ We are grateful to Scott Baier, Jeff Bergstrand, Rick Bond, Carlos Cinquetti, Thibeault Fally, Joseph François, Tomohiko Inui, Paul Jensen, Mario Larch, Nuno Limao, Vibhas Madan, Thierry Mayer, Peter Neary, Maria Olivero, Javier Reyes, Robert Staiger, Costas Syropoulos and Daniel Trefler for helpful comments and discussions. We also thank participants at the Western Economic Association Meetings 2009, the Fall 2009 Midwest International Trade Conference, the 2011 Canadian Economic Association Meetings, the 2011 NBER Summer Institute, the 2011 Econometric Society European Meeting and the LACEA-TIGN III Annual Conference, as well as department seminar participants at Boston College, Drexel University, Fordham University, Oxford University, Paris School of Economics/Sciences Po, the University of Nottingham, the University of Toronto and the World Bank. All errors are ours only.

${ }^{\dagger}$ Contact information: James E. Anderson, Department of Economics, Boston College, Chestnut Hill, MA 02467, USA. Yoto V. Yotov, Department of Economics, Drexel University, Philadelphia, PA 19104, USA. 


\section{Introduction}

The proliferation of regional trade agreements in the 1990's alarmed many trade policy analysts and popular observers because trade diverted from non-partners reduces their terms of trade. The harm to outsiders could potentially outweigh the terms of trade gains to partners, reducing the efficiency of the world trading system. This paper calculates the terms of trade effects, and a novel measure of the global efficiency effects, of 1990's trade agreements in 2 digit manufacturing sectors. The results are reassuring: regionalism delivered benefits while negligibly harming outsiders. Some countries gain over 10\%, a few lose less than $0.2 \%$ and global efficiency rises $0.62 \%$.

Theory gives great prominence to the terms of trade effects of trade agreements while simulation models illustrate the theory with numerical measures of terms of trade changes due to tariff changes. In contrast, there is little empirical evidence on the effect of trade agreements on the terms of trade, because terms of trade are notoriously hard to measure and there are difficult inference problems with ascribing causation. ${ }^{1}$ Our solution is to estimate volume effects using the empirical gravity model, and then deduce their terms of trade implications using the restrictions of structural gravity. This intensive use of the structure is justified by the remarkable confirmation of structural gravity in Anderson and Yotov (2010b).

We extend a large empirical gravity literature on the trade volume effects of Free Trade Agreements (FTAs). Notable studies include Frankel (1997), Magee (2003) and Baier and

\footnotetext{
${ }^{1}$ Feenstra (2004, pp. 197-99) reviews the literature. Studies using prices directly are quite limited in scope due to the difficulties in assembling comparable price data across a wide range of countries as well as inferring the effect of FTAs on prices. Chang and Winters (2002) address both problems using export unit values at the 6 digit Harmonized System level for Brazil. See their footnote 5, pp. 891-2, for discussion of the severe limitations. They treat prices as set by a foreign and domestic firm in a duopoly pricing game that avoids general equilibrium considerations. Clausing (2001) uses a partial equilibrium model disaggregated by sector that links import volume changes to tariff changes for Canada, and does not go on to link them to price changes. Romalis (2007) simulates the equilibrium price changes induced by the Canada-US Free Trade Agreement (CUSFTA) and the North American Free Trade Agreement (NAFTA) tariff changes using detailed demand elasticities estimated with a "difference in differences based estimation technique to identify demand elasticities that focuses on where each of the NAFTA partners sources its imports of almost 5,000 6-digit Harmonized System (HS-6) commodities and comparing this to the source of European Union (EU) imports of the same commodities. The technique enables identification of NAFTAs effects on trade volumes even when countries production costs shift." Caliendo and Parro (2011) calculate what proportion of NAFTA members trade changes can be accounted for by the tariff changes using the Eaton-Kortum (2002) version of the gravity model.
} 
Bergstrand (2002, 2004, 2007). Early findings on the effects of FTAs and trading blocs on bilateral trade flows were mixed, ${ }^{2}$ but recent developments deal effectively with two way causality and show that trading blocs and free trade agreements have large direct effects on aggregate bilateral trade between member countries relative to non-member countries. Baier and Bergstrand (2007) find that, on average, a FTA induces approximately a 100\% increase in bilateral trade between member relative to non-member countries within ten years from their inception. Volume changes like these, larger than explicable by tariff changes, are plausible because FTAs typically induce unobservable trade cost reductions alongside the formal tariff reductions that are the direct object of the agreement. Nontariff policy barriers typically fall between FTA partners ${ }^{3}$ while the enhanced security of bilateral trade induces relationship-specific investment in trade with partner counterparties. Compared to Romalis (2007), focused on tariff changes in NAFTA, our approach focuses on these induced changes.

The bilateral volume effects of FTAs lower bilateral trade costs between partners directly while general equilibrium effects of FTAs indirectly change multilateral resistance (the sellers' and buyers' incidence of trade costs) of every country in the world. General equilibrium also links changes in sellers' incidence to changes in sellers' prices while buyers' prices move with buyers' incidence measured by inward multilateral resistance. These price changes are consistently aggregated into terms of trade changes, the change in the ratio of the index of sellers' prices to the index of buyers' prices.

Our methods are applied to the free trade agreements implemented between 1990 and 2002. In contrast to much of the empirical gravity literature that uses aggregate data, we estimate trade gravity equations disaggregated at the 2 digit ISIC level in manufacturing. We find large volume effects comparable to the aggregate estimates of Baier and Bergstrand (2007) but varying across sectors. We use structural gravity to

\footnotetext{
${ }^{2}$ For example, Bergstrand (1985) found insignificant European Community (EC) effects on bilateral member's trade and Frankel et al (1995) supported his findings. Frankel (1997) found significant Mercosur effects on trade flows but even negative EC effects on trade in certain years. Frankel (1997) also provides a summary of coefficient estimates of the FTA effects from different studies. Ghosh and Yamarik (2004) perform extreme-bounds analysis to support the claim that the FTA effects on trade flows are fragile and unstable.

${ }^{3}$ Canadian support for the CUSFTA was based primarily on its provision for bi-national review of US antidumping procedures, a benefit not measurable by reduction of already low tariffs.
} 
calculate the effect of FTAs on buyers' and sellers' incidence and the associated sellers' price changes in 40 separate countries and an aggregate region consisting of 24 additional nations (none of which entered FTAs).

The results show that the 1990's FTAs significantly increased real manufacturing income of most economies in the world. 10 out of the 40 countries had terms of trade gains greater than $5 \%$ while gains of $10 \%$ or more were enjoyed by Bulgaria, Hungary and Poland. Losses were smaller than $-0.2 \%$ and confined to countries that did not enter into FTAs: Australia, China, Korea and Japan (and the rest of the world aggregate). ${ }^{4}$

FTAs change trade flows and thus, using the iceberg melting metaphor of gravity, how much of the iceberg melts. The metaphor is quantified with an intuitive and novel measure of the global efficiency of distribution averaged over all bilateral shipments in all sectors. We apply the distance function (Deaton, 1979), itself an application of Debreu's coefficient of resource utilization (1951). The global efficiency of trade rises in each manufacturing sector (ranging from $0.11 \%$ for Minerals to $2.1 \%$ for Textiles) with an overall efficiency gain of $0.62 \%$.

A NAFTA counter-factual experiment reveals large benefit to Mexico. Most of Mexico's gains disappear if NAFTA is switched off, while without NAFTA the US and Canada would have lost a little from the FTA inceptions in the rest of the global economy.

The structural gravity model used here nests within a family of models as a separable module focused on the general equilibrium of manufactured goods trade flows across regions. Our base model has endowments on the supply side with nested CobbDouglas/Constant Elasticity of Substitution (CES) demand for national varieties of inputs within each sector on the demand side. The model is fully equivalent to the Ricardian general equilibrium model of Eaton and Kortum (2002) subject to fixed labor supply to manufacturing in each country. In the Ricardian interpretation the terms of trade is interpreted as the real wage, substitution in trade flows is on the extensive mar-

\footnotetext{
${ }^{4}$ The positive sum feature of these results, in contrast to the usual zero-sum implication of simple trade policy theory, arises for two reasons. First, directly, less of the iceberg melts in bilateral shipments between FTA partners due to a reduction in border frictions. Second, the change in all bilateral trade flows at given border frictions can raise or lower the total amount melted. The results show that the combination is positive, though in principle it need not be.
} 
gin rather than the intensive margin and the CES elasticity of substitution parameter is replaced by the comparative advantage parameter (plus one). The endowments and Ricardian assumptions bracket a range of finite elasticities of transformation in supply within manufacturing, suggesting that our results are relatively insensitive to the specification of substitutability. Our approach avoids building a complete general equilibrium model, taking a stand on specification and parameter estimation of many dubious structural components, prominently including missing information on end users of imported intermediate goods. ${ }^{5}$

For the benchmark case we assume that no rents are contained in the trade costs. We thus avoid measuring and modeling many unobservable rents on inward and outward trade while symmetrically suppressing the observable tariff revenue changes that are a very small part of the income changes in most countries because tariffs are generally low. Our main results are robust to the alternative assumption that all rents are tariffs and all tariff revenue is fully rebated. National gains remain for almost all partners, ${ }^{6}$ while some big gains remain (e.g. Poland), some other big gains are considerably reduced (e.g., Mexico).

Section 1 presents the theoretical foundation. Section 2 discusses the estimation of the gravity equation and the trade volume effect of FTAs. Section 3 presents the terms of trade and global efficiency effects of switching on the FTAs of the 1990's in the base year 1990. Section 4 concludes with some suggestions for further research.

\footnotetext{
${ }^{5}$ The terms of trade changes we measure are impact effects within larger structures that allow for substitution between manufacturing and non-manufacturing or for more general substitution within manufacturing. Standard implications of maximizing behavior with substitution imply that, under the endowments assumption, for given price changes our estimates are lower bounds of the real income gains from FTAs via terms of trade effects. But terms of trade will shift further with substitution, presumptively reducing the size of price changes. These effects may cancel out, as they do in the Ricardian interpretation that implies infinite elasticity of substitution across manufacturing sectors, yielding the same terms of trade effects as the endowments model. In the un-modeled full general equilibrium of supply, the Ricardian impact effect is modified as labor will flow into or out of manufacturing. Despite these differences, our counterfactual estimates are comparable in magnitude with those from a series of complex CGE studies.

${ }^{6}$ We only find two cases, Morocco and Tunisia, where revenue losses can potentially outweigh ToT gains. Their manufacturing sectors are small and there are missing terms of trade gains that presumably accrue to agriculture and other natural resource industries.
} 


\section{Theoretical Foundation}

Each country has an endowment vector of the manufacturing goods for which we have data. Alternatively and equivalently, the vector of manufacturing supplies is determined by a Ricardian model of the Eaton-Kortum (2002) type extended to multiple sectors by Costinot, Donaldson and Komunjer (2011) while subject to a fixed supply of manufacturing labor in each country. These alternative models bracket the family of imperfectly substitutable supply models with the two extremes of zero and infinite elasticity of transformation while completely suppressing interaction with the non-manufacturing sectors of the world economy. In either interpretation, all manufactured goods are intermediate. The development below uses the fixed endowment/Armington technology interpretation of the model. The equivalence of the two models is thoroughly explicated in Arkolakis, Costinot and Rodriguez-Clare (2011). ${ }^{7}$ The connection to the Ricardian interpretation is noted below only where needed.

We measure the terms of trade effects component of the standard decomposition of welfare changes (e.g., Anderson and Neary, 2005), not attempting to calculate the marginal deadweight loss effects that embody rent changes, many of which are invisible. All trade costs and their changes are treated as 'real' in our benchmark treatment. We also compute the change in tariff revenues induced by FTAs to compare it with the terms of trade effects. We are forced by lack of data to ignore quota rents (which are large for some country pairs and product lines but notoriously hard to measure), monopoly rents associated with market structure and asymmetric information, extortion and so forth. ${ }^{8}$

Goods are differentiated by place of origin within each goods class. Each goods class forms a weakly separable group in demand with a Constant Elasticity of Substitution (CES) aggregator cost function that is identical across countries. Technologi-

\footnotetext{
${ }^{7}$ They also note that the familiar monopolistic competition model with free entry is qualitatively similar but quantitatively different as fixed production cost absorbs resources and the changes in firm numbers shift the CES 'distribution parameters'. In the absence of believable information on fixed costs and firm entry/exit, we eschew developing the monopolistic competition version of our model.

${ }^{8}$ Anderson and van Wincoop (2002) perform a gravity model based simulation of NAFTA's effects where tariff revenue changes combine with terms of trade changes. Terms of trade changes are far more important than revenue changes in the net welfare effects. That study points out that gravity does a far better job of predicting the actual bilateral trade flow changes than did any of the Computable General Equilibrium (CGE) models surveyed.
} 
cal requirements at the upper, inter-sectoral, level are for convenience represented by a Cobb-Douglas aggregator function, which translates into constant expenditure shares $\alpha_{k}$, $\sum_{k} \alpha_{k}=1$, across sectors within manufacturing.

The technology assumptions together with iceberg trade costs (distribution uses resources in the same proportion as production) imply trade separability: sellers' prices and consumer expenditures are affected only by the aggregate incidence of trade costs in each sector, independent of the details of the distribution of sales or purchases across trading partners. Buyers' incidence falls on user prices while sellers' incidence falls on factory-gate prices.

\section{$1.1 \quad$ Structural Gravity}

Let $p_{i j}^{k}$ denote the price of origin $i$ goods from class $k$ for region $j$ users. The arbitrage condition implies $p_{i j}^{k}=p_{i}^{* k} t_{i j}^{k}$, where $t_{i j}^{k} \geq 1$ denotes the trade cost factor on shipment of goods in class $k$ from $i$ to $j$, and $p_{i}^{* k}$ is the factory-gate price at $i$. Effectively it is as if goods melt away in distribution so that 1 unit shipped becomes $1 / t_{i j}^{k}<1$ units on arrival.

Cost minimizing buyers of inputs using the globally common CES technology have expenditure on goods of class $k$ shipped from origin $i$ to destination $j$ given by:

$$
X_{i j}^{k}=\left(\beta_{i}^{k} p_{i}^{* k} t_{i j}^{k} / P_{j}^{k}\right)^{1-\sigma_{k}} E_{j}^{k}
$$

Here $E_{j}^{k}$ is country $j$ 's expenditure on goods of class $k$ while in the CES share expression preceding it $\sigma_{k}$ is the elasticity of substitution for goods' class $k,{ }^{9} \beta_{i}^{k}$ is a CES share parameter, and $P_{j}^{k}=\left[\sum_{i}\left(\beta_{i}^{k} p_{i}^{* k} t_{i j}^{k}\right)^{1-\sigma_{k}}\right]^{1 /\left(1-\sigma_{k}\right)}$ is a CES price index (subsequently will be interpreted as buyers' incidence of trade costs).

Now consider the supply side and market clearance. The iceberg trade cost metaphor implies that we can treat the value of shipments at end user prices, $Y_{i}^{k}$ for country $i$ and

\footnotetext{
${ }^{9}$ Recent developments in the empirical trade literature suggest that the elasticity of substitution varies across countries. See Broda et al (2006). In the empirical analysis however, we do not allow the elasticity to vary across countries.
} 
goods class $k$, as the product of the price at the factory gate $p_{i}^{* k}$ times the endowment $q_{i}^{k}$, some of which is used up in getting to the end users. $Y_{i}^{k}=p_{i}^{* k} q_{i}^{k}$ because end users must pay the full production plus distribution cost.

Market clearance (at delivered prices) for goods in each class from each origin implies

$$
Y_{i}^{k}=\sum_{j}\left(\beta_{i}^{k} p_{i}^{* k}\right)^{1-\sigma_{k}}\left(t_{i j}^{k} / P_{j}^{k}\right)^{1-\sigma_{k}} E_{j}^{k}, \quad \forall k
$$

Define $Y^{k} \equiv \sum_{i} Y_{i}^{k}$ and divide the preceding equation by $Y^{k}$ to obtain:

$$
\left(\beta_{i}^{k} p_{i}^{* k} \Pi_{i}^{k}\right)^{1-\sigma_{k}}=Y_{i}^{k} / Y^{k}
$$

where $\left(\Pi_{i}^{k}\right)^{1-\sigma_{k}} \equiv \sum_{j}\left(t_{i j}^{k} / P_{j}^{k}\right)^{1-\sigma_{k}} E_{j}^{k} / Y^{k}$.

The derivation of the structural gravity model is completed using (3) to substitute for $\beta_{i}^{k} p_{i}^{* k}$ in (1), the market clearance equation and the CES price index. Then:

$$
\begin{aligned}
X_{i j}^{k} & =\frac{E_{j}^{k} Y_{i}^{k}}{Y^{k}}\left(\frac{t_{i j}^{k}}{P_{j}^{k} \Pi_{i}^{k}}\right)^{1-\sigma_{k}} \\
\left(\Pi_{i}^{k}\right)^{1-\sigma_{k}} & =\sum_{j}\left(\frac{t_{i j}^{k}}{P_{j}^{k}}\right)^{1-\sigma_{k}} \frac{E_{j}^{k}}{Y^{k}} \\
\left(P_{j}^{k}\right)^{1-\sigma_{k}} & =\sum_{i}\left(\frac{t_{i j}^{k}}{\Pi_{i}^{k}}\right)^{1-\sigma_{k}} \frac{Y_{i}^{k}}{Y^{k}}
\end{aligned}
$$

(4)-(6) is the structural gravity model. $\Pi_{i}^{k}$ denotes outward multilateral resistance (OMR), while $P_{j}^{k}$ denotes inward multilateral resistance (IMR).

Outward multilateral resistance is the average sellers' incidence. It is as if each country $i$ shipped its product $k$ to a single world market facing supply side incidence of trade costs of $\Pi_{i}^{k}$. (3) is interpreted as the market clearance condition for a hypothetical world market where a single representative buyer purchases variety $i$ in class $k$ at price $p_{i}^{* k} \Pi_{i}^{k}{ }^{10}$

Inward multilateral resistance in (6) is a CES index of bilateral buyers' incidences $t_{i j}^{k} / \Pi_{i}^{k}$. It is as if each country $j$ bought its vector of class $k$ goods from a single world

\footnotetext{
${ }^{10}$ The CES cost index for this hypothetical user in the world market is conventionally equal to 1 due to summing (3) over $i$.
} 
market facing demand side incidence of $P_{j}^{k}$.

The equilibrium factory gate prices $p_{i}^{* k}$ reflect the forces of supply and demand in the global economy and also the sellers' incidence of trade costs facing the entire global economy, channeled through sellers' incidence. Thus,

$$
p_{i}^{* k}=\frac{\left(Y_{i}^{k} / Y_{k}\right)^{1 /\left(1-\sigma_{k}\right)}}{\beta_{i}^{k} \Pi_{i}^{k}} .
$$

Due to $(3), p_{i}^{* k}$ is decreasing in $\Pi_{i}^{k}$, a connection tying terms of trade effects of FTAs to the incidence analysis of the gravity model. In conditional general equilibrium with given $Y_{i}^{k}$ 's, the relationship is the simple inverse one given above: a fall in incidence raises factory gate prices one for one. But in general equilibrium $Y_{i}^{k} / Y^{k}$ is also a function of the $p^{*}$ 's and the solution for the $p^{*}$ 's reflects supply and demand conditions and sellers' incidence in all markets simultaneously.

\subsection{Incidence and Total Effects of Free Trade Agreements}

The procedure in the existing literature for estimating FTA effects on bilateral trade flows is to account for the presence of free trade agreements in the definition of the unobservable trade costs, $t_{i j}^{k}$, in the structural gravity equation (4). For a generic good, we define:

$$
t_{i j}^{1-\sigma}=e^{\beta_{1} F T A_{i j}+\beta_{2} \ln D I S T_{i j}+\beta_{3} B R D R_{i j}+\beta_{4} L A N G_{i j}+\beta_{5} C L N Y_{i j}+\sum_{i=6}^{46} \beta_{i} S M C T R Y_{i j}} .
$$

Here, $F T A_{i j}$ is an indicator variable for a free trade agreement between trading partners $i$ and $j . \ln D I S T_{i j}$ is the logarithm of bilateral distance. BRDR $R_{i j}, L A N G_{i j}$ and $C L N Y_{i j}$ capture the presence of contiguous borders, common language and colonial ties, respectively. Finally, we follow Anderson and Yotov (2010b) to define $S M C T R Y_{i j}$ as a set of country-specific dummy variables equal to 1 when $i=j$ and zero elsewhere, which capture the effect of crossing the international border by shifting up internal trade, all else equal. ${ }^{11}$

\footnotetext{
${ }^{11}$ It should be noted that while controlling for internal trade has been ignored in the vast majority of gravity estimates, the few studies that do include a variant of our SMCTRY covariate always estimate large, positive and significant coefficient estimates on this dummy. For example, Wolf (2000) finds
} 
It is clear from system (4)-(6) that the direct effect of free trade agreements on bilateral trade flows, measured by $\beta_{1}$ in (7), is only a fraction of the total FTA impact, which includes two additional indirect effects. The first additional FTA effect is channeled through the multilateral resistance terms. For given output and expenditures, system (5)-(6) maps changes in bilateral trade costs to changes in the multilateral resistances. Consequently, (4) reveals that any MR changes will affect bilateral trade flows. The second indirect FTA effect on trade flows is channeled through output and expenditures, which enter (4) directly, but also are structural elements in the construction of the multilateral resistance indexes. This indirect effect requires accounting for the FTA-driven changes in output and expenditures at the upper level equilibrium. In sum, in order to estimate total FTA effects, one has to estimate FTA impact through the multilateral resistances and through changes in output and expenditures, in addition to the direct FTA effects on bilateral trade costs. We describe such a comprehensive procedure next.

As input to the evaluation, we estimate the $\left(t_{i j}^{k}\right)^{1-\sigma_{k}}$ 's with and without the FTA imposed with panel methods. We take the initial year, pre-FTA, and choose units such that $p_{i}^{* k}=1, \forall i, k$. This implies that the endowments are observed from the initial $Y_{i}^{k}$ 's. The distribution parameters $\left(\beta_{i}^{k}\right)^{1-\sigma_{k}}, \forall i, k$ are solved from the base year market clearance equations (10) given below. See Section 3.1 for details.

To calculate the full effect of FTAs we conduct the counter-factual experiment of putting the FTA effect (using the $t_{i j}^{k}$ 's from later years) into the base year with fixed endowments. We find the set of factory gate prices and inward and outward multilateral resistances that results. Once we know the $p^{*}$ 's we can generate the $Y$ 's, the expenditures (E's) and the incidence variables, the $P$ 's and $\Pi$ 's. The level of the incidence variables is subject to the normalization of the $\beta_{i}^{k}$ 's, but their proportional change is invariant to to the normalization.

evidence of US state border effects using aggregate shipments data. In the case of Canadian commodity trade, Anderson and Yotov (2010a) find that internal provincial trade is higher than interprovincial and international trade for 19 non-service sectors during the period 1992-2003. In a complementary study, Anderson et al (2011) obtain similar estimates for Canadian service trade. Jensen and Yotov (2011) estimate very large and significant $S M C T R Y$ impact for important agricultural commodities in the world in 2001. Finally, Anderson and Yotov (2010b) estimate significant, country-specific SMCTRY effects for 18 manufacturing sectors in the world (76 countries), 1990-2002. 
The supply shares under this setup are given by

$$
\frac{Y_{i}^{k}}{Y^{k}}=\frac{p_{i}^{* k} q_{i}^{k}}{\sum_{i} p_{i}^{* k} q_{i}^{k}}, \forall i, k
$$

for each sector and country. The demand shares are given by

$$
\frac{E_{j}^{k}}{Y^{k}}=\frac{\phi_{j} \sum_{k} p_{j}^{* k} q_{j}^{k}}{\sum_{j} \phi_{j} \sum_{k} p_{j}^{* k} q_{j}^{k}}, \forall j, k
$$

The demand share on the right hand side of (9) uses the assumption of identical CobbDouglas technology at the upper level to set country $j$ 's share of world spending on goods of class $k$ as the ratio of $j$ 's spending on all goods to world spending on all goods. Here $\phi_{j}>0$ is the ratio of total expenditure to income for manufacturing as a whole in country $j . \quad \phi_{j} \neq 1$ allows for nationally varying manufacturing trade imbalance. ${ }^{12}$ In keeping with avoidance of a full general equilibrium treatment of the link between manufacturing and the rest of the economy, $\phi_{j}$ is assumed to be constant in the comparative static experiments below.

There are NK $p^{*}$ 's that change from their initial value equal to 1 when the $t$ 's change due to the FTA experiment. They are solved from the market clearance equations, given the $\beta$ 's and $q$ 's which we construct in the empirical section,

$$
\frac{p_{i}^{* k} q_{i}^{k}}{\sum_{i} p_{i}^{* k} q_{i}^{k}}=\sum_{j}\left(\beta_{i}^{k} p_{i}^{* k} t_{i j}^{k} / P_{j}^{k}\right)^{1-\sigma_{k}} \frac{\sum_{k} \phi_{j} p_{j}^{* k} q_{j}^{k}}{\sum_{j, k} \phi_{j} p_{j}^{* k} q_{j}^{k}}, \forall i, k
$$

where

$$
\left(P_{j}^{k}\right)^{1-\sigma_{k}}=\sum_{i}\left(\beta_{i}^{k} p_{i}^{* k} t_{i j}^{k}\right)^{1-\sigma_{k}}, \forall j, k
$$

and (9) is utilized to replace $E_{j}^{k} / Y^{k}$ on the right of the right hand side of (10).

There are NK equations in (10) and another NK in (11). As with any neoclassical market clearing conditions, a normalization of prices is required because the system is homogeneous of degree zero in the vector of factory gate prices. A natural normalization

\footnotetext{
${ }^{12}$ If all goods were included in $K$ and total trade was balanced, $\phi_{j}=1, \forall j$. Variation in $\phi$ 's is not an important concern, because in our application the results are almost completely insensitive to setting $\phi_{j}=1, \forall j$.
} 
is one that holds world real resources constant:

$$
\sum_{i, k} p_{i}^{* k} q_{i}^{k}=\sum_{i, k} p_{i}^{* k 0} q_{i}^{k}
$$

In the Ricardian interpretation, using $p_{i}^{* k}=w_{i} a_{i}^{k}$ for goods that are produced along with the labor market clearance condition $\sum_{k} a_{i}^{k} q_{i}^{k}=L_{i}$, (12) becomes the normalization of wages $\sum_{i} w_{i} L_{i}=\sum_{i} w_{i}^{0} L_{i}$. In the calculations below, by choice of units $p_{i}^{* k 0}=1$.

In (10)-(11), due to separability and homotheticity, only 2NK-K equations are linearly independent, so (12) must apply in each sector in equilibrium: $\sum_{i} q_{i}^{k}=\sum_{i} p_{i}^{* k} q_{i}^{k}, \forall k$. To see this, let $\mathbf{p}^{1 k} \equiv\left\{p_{i}^{* k}\right\}$, denote the vector of equilibrium factory gate prices in sector $k$ in some particular equilibrium with the new $t$ 's. At this equilibrium $\mathbf{p}^{1 k}$, a scalar shift $\lambda^{k}$ in $\mathbf{p}^{k}$ raises the $P_{j}^{k}$ 's equiproportionately. Then for the block of equations for sector $k$ within (10), conditional on the initial equilibrium value of $\sum_{k} p_{j}^{* k} q_{j}^{k} / \sum_{i, k} p_{i}^{* k} q_{i}^{k}=$ $\lambda^{k} \sum_{k} p_{i}^{1 k} q_{j}^{k} / \sum_{i, k} q_{i}^{k}$ under the normalization (12), the equation block continues to hold. Consistency with normalization (12) requires $\lambda^{k}=1, \forall k$.

The incidence of the trade cost changes is implied by the multilateral resistance system (5)-(6). In practice, since the P's are already solved for from (10)-(12), the $\Pi$ 's are solved recursively using the solution $P$ 's in (5). ${ }^{13}$

\subsection{National Gains Measures}

Accounting for the effect of trade cost changes on manufacturing real income in this setup is very simple. For each good in each country, there is a 'factory gate' price (unit cost of production and distribution) $p_{i}^{* k}$ in country $i$ and product $k$. National manufacturing income with multiple goods is given by $\sum_{k} p_{i}^{* k} q_{i}^{k}$. Buyers in $i$ face price indexes $P_{i}^{k}$ for

\footnotetext{
${ }^{13}$ This solution is consistent with solving (5)-(6) for the supply and expenditure shares implied by the solution $p^{*}$ 's and normalizing the П's by

$$
\sum_{i}\left(\beta_{i}^{k}\right)^{1-\sigma_{k}}\left(p_{i}^{* k} \Pi_{i}^{k}\right)^{1-\sigma_{k}}=1, \forall k
$$

(13) arises from interpreting the global sales pattern $\left\{Y_{i}^{k} / Y^{k}\right\}$ as arising from sales to a hypothetical 'world' consumer with CES preferences, resulting in $Y_{i}^{k} / Y^{k}=\left(\beta_{i}^{k} p_{i}^{* k} \Pi_{i}^{k}\right)^{1-\sigma_{k}}$ where the hypothetical CES global price index is equal to 1 .
} 
goods class $k$. The user cost index for all goods is given by $C_{i}=\exp \left(\sum_{k} \alpha_{k} \ln P_{i}^{k}\right)$. Then real income $R_{i}=\sum_{k} p_{i}^{* k} q_{i}^{k} / C_{i}=T_{i} \sum_{k} q_{i}^{k}$, i's real product $\sum_{k} q_{i}^{k}$ (under normalization (12)) times $i$ 's terms of trade $T_{i}$ given by

$$
T_{i}=\frac{\sum_{k} p_{i}^{* k} q_{i}^{k} / \sum_{k} q_{i}^{k}}{C_{i}}
$$

$T_{i}$ is the ratio of the exact price index of exportable goods to the 'true' cost index of importable goods, the standard definition of the terms of trade. Under the Ricardian interpretation of the production model, the numerator of (14) is replaced by country $i$ 's manufacturing wage $w_{i}$, so $T_{i}$ is the 'real wage'. Let $a_{i}^{k}$ denote the unit labor requirement for sector $k$ in country $i$. For all goods that are actually produced by country $i, p_{i}^{* k}=a_{i}^{k} w_{i}$ while $q_{i}^{k} a_{i}^{k}=L_{i}^{k}$. Substituting into (14), the right hand side becomes $w_{i} / C_{i}$.

The effect on real manufacturing income in country $i$ from a switch from No FTA (denoted with superscript 0) to FTA (denoted with superscript $F$ ) can be evaluated by computing the proportional real income change with the ratio $R_{i}^{F} / R_{i}^{0}$, equal to the proportionate change in the terms of trade $T_{i}^{F} / T_{i}^{0} \cdot{ }^{14}$

When rents are present, the FTAs alter the size of the rents and affect real social income. The welfare accounting procedure incorporates the rent changes into social income and into the income/expenditure link. Keeping the focus on manufacturing income, ignore the cross effects between manufacturing price changes and rents other than manufacturing tariffs. Social income from manufacturing is the sum of producer payments and

\footnotetext{
${ }^{14} \mathrm{~A}$ more formal treatment using the GDP function clarifies the relationship between our approach focused on the manufacturing sectors and a full analysis of all sectors. Let the maximum value GDP function be denoted $g\left(\pi, \mathbf{p}^{*}, \mathbf{P}, v\right)$ for a generic country, where $\pi$ denotes the tradable goods price vector in the rest of the economy, $\mathbf{p}^{*}$ the factory gate manufacturing price vector and $\mathbf{P}$ the manufacturing input price vector. Differentiating GDP with respect to the manufacturing prices and using Hotelling's and Shephard's Lemmas, the proportional rate of change of GDP is

$$
\hat{g}=\frac{\sum_{k} Y^{k}}{g}\left[\sum_{k} w^{k} \hat{p}^{* k}-\sum_{k} \omega^{k} \hat{P}^{k}\right]+\frac{\sum_{k}\left(E^{k}-Y^{k}\right)}{g} \sum_{k} \omega^{k} \hat{P}^{k}
$$

where $w^{k}=Y^{k} / \sum_{k} Y^{k}$ and $\omega^{k}=E^{k} / \sum_{k} E^{k}$. The square bracket term on the right hand side is the percentage change in the terms of trade. It is multiplied by the importance of manufacturing in GDP, a scaling factor we disregard. The second term on the right is equal to zero under balanced trade. While this is not generally true for any subset of sectors, the normal convention is to impose it when all sectors are included, so we suppress this term in our treatment. Equation (14) follows by integrating the square bracket under the restrictions of fixed $q$ 's and a Cobb-Douglas cost function $C$ for input prices.
} 
the manufacturing trade rent that is retained nationally and not wasted. The retained rent in each country $j$ is

$$
G_{j}=\sum_{i, k} \alpha_{k}\left(\frac{t_{i j}^{k}}{\Pi_{i}^{k} P_{j}^{k}}\right)^{1-\sigma_{k}} E_{j} \tau_{i j}^{k}+\sum_{i, k} \alpha_{k}\left(\frac{t_{j i}^{k}}{\Pi_{j}^{k} P_{i}^{k}}\right)^{1-\sigma_{k}} E_{i} \tau_{j i}^{k} .
$$

The right hand side of the equation gives the rent collected on imports plus the rent collected on exports. The import rent is the sum of expenditure shares in $j$ times the ad valorem rent retention 'parameter' $\tau_{i j}^{k}$ on the domestic price base, ${ }^{15}$ while the export rent has the analogous structure. $G_{j}$ depends on the rent retention parameters directly and also via the $t_{i j}^{k}$ s. Expenditure in $j$ is now given by $E_{j}=\phi_{j}\left(G_{j}+\sum_{k} p_{j}^{* k} q_{j}^{k}\right)$ where, as previously $\phi_{j} \neq 1$ is a constant reflecting comparative advantage and income/expenditure imbalance. The budget constraint solves for equilibrium social expenditure $S_{j}$ as the producer payments $\sum_{k} p_{j}^{* k} q_{j}^{k}$ times the rent multiplier $m_{j}:{ }^{16}$

$$
S_{j}=m_{j} \sum_{j} p_{j}^{* k} q_{j}^{k}
$$

where

$$
m_{j}=\frac{\phi_{j}}{1-\phi_{j}\left(\sum_{i, k} \alpha_{k}\left(t_{i j}^{k} / \Pi_{i}^{k} P_{j}^{k}\right)^{1-\sigma_{k}} \tau_{i j}^{k}+\sum_{i, k} \alpha_{k}\left(t_{j i}^{k} / \Pi_{j}^{k} P_{i}^{k}\right)^{1-\sigma_{k}} \tau_{j i}^{k}\right)} .
$$

The equilibrium prices are altered from the no rents case by the effect of the retained rent because in the market clearance conditions (10) $S_{j}$ defined by (16) replaces $\sum_{k} p_{j}^{* k} q_{j}^{k}$.

Real social income in country $j$ is given by $T_{j} m_{j} \sum_{k} q_{j}^{k}$, with proportionate change due to the FTAs given by $T_{j}^{F} / T_{j}^{0}$ times $m_{j}^{F} / m_{j}^{0}$, the terms of trade effect times the multiplier effect. This decomposition has a straightforward connection to the standard decomposition of the effect of tariff changes for the case where $\tau \mathrm{s}$ are all tariffs. ${ }^{17}$

\footnotetext{
${ }^{15} \tau_{i j}^{k}=\tau_{i j}^{* k} /\left(1+\tau_{i j}^{* k}\right)$ where $\tau_{i j}^{* k}$ is the usual ad valorem rent retention parameter on the foreign price base. In the case of fully rebated tariffs, $\tau_{i j}$ is the ad valorem tariff applied bilaterally by country $j$ on shipments from $i$ in goods class $k$.

${ }^{16}$ See Anderson and van Wincoop, 2002, for more discussion in the special case where $\phi_{j}=1$ and there is only one goods class.

${ }^{17} t_{i j}^{k}$ includes a multiplicative tariff factor. Differentiating (16) with respect to a tariff change, and netting out the transfer between government and private sector yields the standard expression decomposing the effect of a small tariff change into a terms of trade (world price) effect and a marginal dead weight loss effect.
} 
In practice, we eschew using (16)-(17) because it gives a misleading impression of fully accounting for rents. In our application we have no information on rents other than tariffs and even for those our information is incomplete. Still less can we infer the effect of FTAs on the retained rent 'parameters' in the absence of both more data and a model of the rent retention. FTAs might well increase rent retention of some types (e.g. less extortion at the border can raise the rents earned by middlemen on both the export and import sides) between partners while reducing tariff revenue.

For sensitivity analysis, we calculate the change in $G_{j}$ given by (15) changes at constant shares and expenditure when $\tau_{i j}$ is the ad valorem tariff and the FTA switches some of these off. These $\Delta G_{j}$ measures are compared to our measures of $\Delta T_{j} \sum_{k} q_{j}^{k}$.

\subsection{World Efficiency Measures}

World efficiency can be evaluated by further exploiting implications of the structural gravity model. The iceberg melting metaphor is extended to a scalar aggregate using the interpretation of outward multilateral resistance as aggregate sellers incidence and inward multilateral resistance as buyers' incidence. Global aggregate sellers' incidence is interpreted as global aggregate shrinkage due to 'melting' prior to arrival on the 'world' market. Global aggregate buyers' incidence is interpreted as the further melting due to shipment from the 'world' market to its various destinations. This natural measure of the FTA-induced change in the global efficiency of distribution is an application of Debreu's (1951) coefficient of resource utilization as specialized in Deaton's (1979) distance function. ${ }^{18}$ Our global efficiency measure reverts to ignoring rents, in keeping with a focus on the efficiency of shipments rather than a complete welfare accounting. ${ }^{19}$

The endowment of world resources is the vector $\left\{q^{k} \equiv \sum_{i} q_{i}^{k}\right\}$. In equilibrium, only a fraction of the endowment arrives at the hypothetical 'world' market for sellers to

\footnotetext{
${ }^{18}$ We choose the distance function approach in preference to a more standard approach that defines a world 'money metric' utility by summing $S_{i}$ as defined by (16), a measure of world real income in numeraire units. The underlying identical homothetic preference/technology structure makes either approach a theoretically valid welfare measure (through transfer between countries of either numeraire income or proportions of world endowment), but the distance function measure retains an attractive efficiency interpretation whether transfers are paid or not.

${ }^{19}$ Rents associated with non-tariff barriers are commonly internationally shared, an important but extremely difficult to observe property of the full accounting requirements.
} 
exchange with buyers because some melts away in shipment to the 'world' market. A further nationally varying fraction melts away as the buyers ship their 'world' market purchases to their destinations. The aggregate sellers (across origins) and buyers (across destinations) melting fractions for each goods class $k$ are derived utilizing structural gravity and the CES technology structure. A further aggregation across the goods classes is derived based on the Cobb-Douglas technology structure of the upper level technology of manufacturing inputs.

Consistent aggregation of sellers' incidence across sources in each goods class $k$ follows from defining the global aggregate sellers' incidence: $\Pi^{k}$ by:

$$
\Pi^{k}\left(\sum_{i}\left(\beta_{i}^{k} p_{i}^{* k}\right)^{1-\sigma_{k}}\right)^{1 /\left(1-\sigma_{k}\right)}=\left(\sum_{i}\left(\beta_{i}^{k} p_{i}^{* k} \Pi_{i}^{k}\right)^{1-\sigma_{k}}\right)^{1 /\left(1-\sigma_{k}\right)}=1
$$

The rightmost equality follows from summing (3): the hypothetical user price index for class $k$ goods for the 'world' user (i.e., the user located in the 'world' market) is equal to 1. The first expression on the left hand side of (18) is the product of the aggregate incidence $\Pi^{k}$ and the hypothetical frictionless equilibrium price index. Exploiting the second equality in (18), the global sales can be interpreted as the product of effective world use $q^{k} / \Pi_{k}$ and the frictionless user price index $\left(\sum_{i}\left(\beta_{i}^{k} p_{i}^{* k}\right)^{1-\sigma_{k}}\right)^{1 /\left(1-\sigma_{k}\right)}$. This is the iceberg melting metaphor in the aggregate.

$\Pi^{k}$ is a CES function of the $\Pi_{i}^{k}$ 's, the (variable) weights being the hypothetical frictionless equilibrium world shares $w_{i}^{k}=\left(\beta_{i}^{k} p_{i}^{* k}\right)^{1-\sigma_{k}} / \sum_{i}\left(\beta_{i}^{k} p_{i}^{* k}\right)^{1-\sigma_{k}}$. Re-writing (18), the CES aggregator in terms of power transforms is

$$
\left(\Pi^{k}\right)^{1-\sigma_{k}}=\sum_{i} w_{i}^{k}\left(\Pi_{i}^{k}\right)^{1-\sigma_{k}}
$$

In the initial situation (without FTAs for example) the factory gate prices in (18) are all equal to one, yielding aggregate sellers incidence $\Pi^{k 0}$. Bringing in the new trade costs (the FTAs) induces new $p^{*}$ 's and new П's, and hence new aggregate effective consumption. Let $\Pi^{k F}$ denote the value of $\Pi^{k}$ in the FTA equilibrium. For each goods class, the effect of the FTA on global efficiency via the sellers' incidence is measured by $\Pi^{k 0} / \Pi^{k F}$. 
On the buyers' side of the market, goods are in effect purchased on the 'world' market in the total amount $q^{k} / \Pi^{k}$. For each destination $j$ the goods are shipped home with further melting such that only $E_{j}^{k} / P_{j}^{k}$ arrives at destination $j$. Or, effectively the buyer covers the full margin $\Pi^{k} P_{j}^{k}$. To aggregate across destinations the global average buyers incidence is defined by

$$
\frac{1}{P^{k}} \equiv \sum_{j} \frac{E_{j}^{k}}{Y^{k}} \frac{1}{P_{j}^{k}} .
$$

Then world use at destination is given by

$$
\frac{q^{k}}{\Pi^{k} P^{k}}
$$

the world endowment of good $k$ is deflated by the product of the appropriate average buyers and sellers incidence.

A scalar measure of the overall efficiency gain requires some sort of weighting across goods classes making use of the hypothetical world market and the identical technology across goods classes. With Cobb-Douglas technology the world efficiency measure is defined by

$$
\frac{1}{\Pi P}=\frac{1}{\exp \left[\sum_{k} \alpha_{k}\left(\ln \Pi^{k}+\ln P^{k}\right)\right]}
$$

where $\alpha_{k}$ is the cost share parameter for goods class $k$. Evaluating $\Pi P$ at initial and FTA trade costs and forming their ratio $\Pi^{0} P^{0} / \Pi^{F} P^{F}$ gives a scalar measure of the global efficiency gain from the shift in trade costs due to the FTA, neatly decomposable into sellers' efficiency change $\Pi^{0} / \Pi^{F}$ times buyers' efficiency change $P^{0} / P^{F}$.

Figure 1 illustrates the logic for the case of two goods classes. E is the endowment point. The line with slope equal to minus 1 through E denotes the initial value of the world endowment. Point $\mathrm{C}$ denotes the initial equilibrium effective consumption of intermediates point $q^{1} / \Pi^{1,0} P^{1,0}, q^{2} / \Pi^{2,0} P^{2,0}$. The isoquant through point $\mathrm{C}$ gives all intermediates consumption vectors $c^{1}, c^{2}$ satisfying $f\left(c^{1}, c^{2}\right)=f\left(q^{1} / \Pi^{1,0} P^{1,0}, q^{2} / \Pi^{2,0} P^{2,0}\right)=f^{0}$. The efficiency of the initial equilibrium is given by the radial contraction along ray OE from E to point A that gives the same level of output of the composite input as the actual effective consumption at $\mathrm{C}$. Thus $1 / \Pi P=O A / O E$. Point $\mathrm{F}$ denotes the FTA equilib- 
rium effective consumption $q^{1} / \Pi^{1 F} P^{1, F}, q^{2} / \Pi^{2 F} P^{2, F}$. The isoquant associated with point F cuts ray $\mathrm{OE}$ at $\mathrm{D}$, with efficiency measure OD/OE. The proportionate efficiency change is $\mathrm{OD} / \mathrm{OA}$.

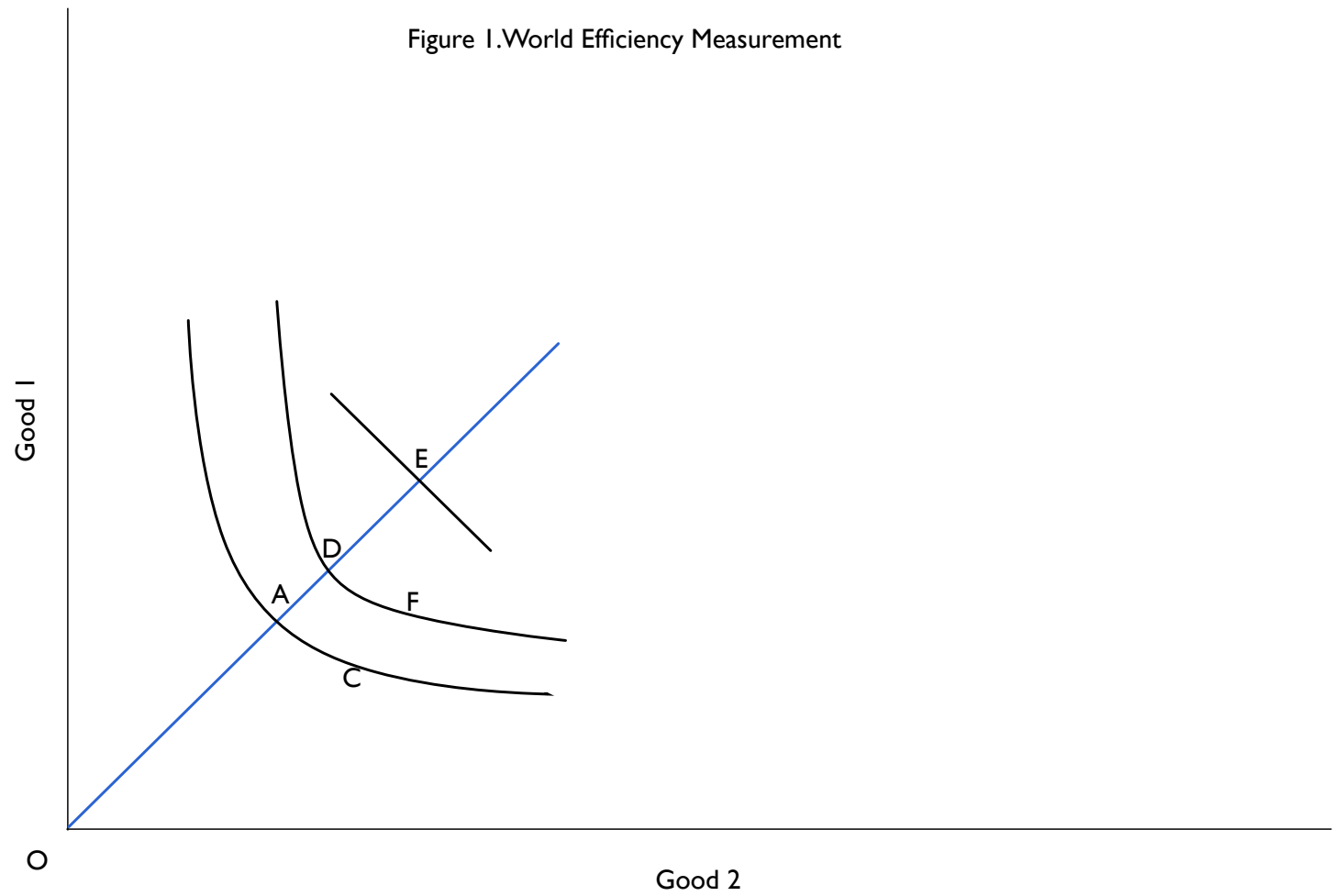

Figure 1 also illustrates the global efficiency measure within each goods class, reinterpreting the goods as varieties within a goods class and the isoquants as aggregators of national varieties, understanding that they have CES structure instead of Cobb-Douglas. The effect of the FTA-induced change in the factory gate equilibrium prices $p_{i}^{* k}$ shifts the weights in (19) as well as each country's sellers' incidence $\Pi_{i}^{k}$.

In the Ricardian interpretation, the same deflator $P \Pi$ applies to the world endowment vector of manufacturing labor $\left\{L_{i}\right\}$. Figure 1 illustrates, after relabeling the axes to measure labor endowments of two countries and interpreting the isoquants as applying to labor services. The hypothetical representative agent's utilization of the world endowment shrinks along endowment ray OE. The underlying logic is that for each bilateral trade the actual value of labor services used in production and distribution $X_{i j}^{k}$ results in labor services utilized at destination equal to $X_{i j}^{k} / t_{i j}^{k}$. The consistent global aggregation of $\left\{t_{i j}^{k}\right\}$ into the scalar $P \Pi$ applies straightforwardly to the value of the world labor endowment. 


\section{Empirical Implementation and Analysis}

\subsection{Econometric Specification}

The econometric specification of gravity is completed by substituting (7) for the power transform of $t_{i j}$ into (4) and then expanding the gravity equation with an error term. To obtain econometrically sound estimates of the parameters of interest must meet the following challenges: presence of zero trade flows; heteroskedasticity in trade flows data; endogeneity of free trade agreements; and, unobservable multilateral resistance terms. To utilize the information carried by the zero trade flows and to account for heteroskedasticity in trade flows data, we resort to the Poisson pseudo-maximum-likelihood (PPML) estimator advocated by Santos-Silva and Tenreyro (2007) who argue that the truncation of trade flows at zero biases the standard log-linear OLS approach and results in inconsistent coefficient estimates. ${ }^{20}$

Following the developments in the empirical gravity literature, we use time-varying, directional (source and destination), country-specific dummies to control for the multilateral resistances along with the sales $\left(Y_{i}^{k}\right)$ and expenditure $\left(E_{j}^{k}\right)$ variables. ${ }^{21}$ To account for FTA endogeneity, we use the panel data estimation techniques described in Wooldridge (2002) and first applied to a similar setting by Baier and Bergstrand (2007), who employ aggregate data to show that direct FTA effects on bilateral trade flows can be consistently isolated in a theoretically-founded gravity model by using country-pair fixed effects. As a robustness check, Baier and Bergstrand (2007) produce alternative FTA estimates with

\footnotetext{
${ }^{20}$ Helpman, Melitz and Rubinstein (2008) (HMR) propose an alternative approach to zero trade flows. They develop a formal model of selection, where exporters must absorb some fixed costs to enter a market. They identify the model using religion as an exogenous variable that enters selection but is excluded from determination of the volume of trade. We choose not to use HMR, partly because of doubts about the exclusion restriction and partly because of doubts about the importance of fixed costs in light of evidence in Besedes and Prusa $(2006 \mathrm{a}, \mathrm{b})$ that highly disaggregated bilateral US trade flickers on and off. Anderson and Yotov (2010b) show that HMR and PPML as well as OLS give essentially the same bilateral trade costs after normalization.

${ }^{21}$ Anderson and van Wincoop (2003) use custom programming to account for the multilateral resistances in a static setting. Feenstra (2004) advocates the directional, country-specific fixed effects approach. To estimate the effects of the Canadian Agreement on Internal Trade (AIT), Anderson and Yotov (2010a) use panel data with time-varying, directional (source and destination), country-specific fixed effects. Olivero and Yotov (forthcoming) formalize their econometric treatment of the MR terms in a dynamic gravity setting.
} 
first-differenced panel data, which eliminates the pair fixed effects. ${ }^{22}$

Taking all of the above considerations into account, we use the PPML technique ${ }^{23}$ to estimate the following econometric specification for each class of commodities in our sample:

$$
X_{i j, t}=\exp \left[\beta_{0}+\eta_{i, t}+\theta_{j, t}+\gamma_{i j}+\beta_{1} F T A_{i j, t}+\beta_{2} F T A_{i j, t-1}+\beta_{3} F T A_{i j, t-2}\right]+\epsilon_{i j, t},
$$

Here, $X_{i j}$ is bilateral trade (in levels) between partners $i$ and $j$ at time $t .{ }^{24} F T A_{i j, t}$ is an indicator variable that takes a value of one if at time $t$ countries $i$ and $j$ are members of the same free trade agreement. $\eta_{i, t}$ denotes the time-varying source-country dummies, which control for the (log of) outward multilateral resistances and total shipments. $\theta_{j, t}$ encompasses the time varying destination country dummy variables that account for the (log of) inward multilateral resistances and total expenditure. $\gamma_{i j}$ captures the countrypair fixed effects used to address FTA endogeneity.

Following Baier and Bergstrand (2007) we specify the FTA volume effects,the $\beta$ 's, to be uniform (as opposed to varying by FTA) and we allow for gradual phasing-in of the free trade agreement effects by including FTA lags in specification (20). The reason for the former is that, due to the rich fixed effects structure of our econometric specification and

\footnotetext{
${ }^{22}$ The issue of FTA endogeneity is not new to the trade literature (see Trefler 1993, for example). However, primarily due to the lack of reliable instruments, standard instrumental variable (IV) treatments of endogeneity in cross-sectional settings have not been successful in addressing the problem. See for example Magee (2003) and Baier and Bergstrand (2002, 2004b). Baier and Bergstrand (2007) summarize the findings from these studies as "at best mixed evidence of isolating the effect of FTAs on trade flows."

${ }^{23}$ Consistency of the PPML estimator arises from the large sample structure of the gravity model. If $N$ is the number of regions and $\tau$ is the number of periods, the number of fixed effects grows at rate $2 N \tau+N^{2}$ while the number of observations grows at rate $N^{2} \tau>>2 N \tau+N^{2}$ as $\tau$ grows. As a robustness check, we also estimated with the first differences technique and obtain essentially the same results as with country fixed effects. (Since first differencing gave rise to some negative values of $\Delta X_{i j, t}$ that PPML cannot handle, our first difference estimator is log-linear, as in Baier and Bergstrand (2007).)

${ }^{24}$ In a static setting, (4) implies that income and expenditure elasticities of bilateral trade flows are unitary and, therefore, size-adjusted trade is the natural dependent variable. Bringing output and expenditures on the left-hand side has the additional advantage of controlling for endogeneity of these variables. Using aggregate data however, Frankel (1997) shows that the bias due to GDP endogeneity is insignificant. In addition, Olivero and Yotov (forthcoming) show that income and expenditure elasticities are not necessarily equal to one in a dynamic setting, such as the one that we employ here to account for FTA endogeneity. Thus, in addition to accounting for the unobserved multilateral resistances, the fixed effects in our estimations will also absorb country-specific output and expenditures. Using disaggregated manufacturing data, Anderson and Yotov (2010b) show that the multilateral resistance component explains about $32.3 \%$ of the variance of the fixed effects, while the size effect terms (output and expenditures) account for about $57.7 \%$ of the fixed effects variability.
} 
the small variability in any individual FTA indicators, we cannot identify separately the effects of specific FTAs. ${ }^{25}$ The reason for the latter is that private agents in the trading partners gradually adjust to the new economic conditions under a recently implemented FTA. From an econometric perspective, allowing for phasing-in adds a time dimension (in addition to the commodity, country, and producer and consumer dimensions) to the data sets of terms of trade (welfare) effects that we construct in the next section.

Finally, as noted by Cheng and Wall (2005), "Fixed-effects estimations are sometimes criticized when applied to data pooled over consecutive years on the grounds that dependent and independent variables cannot fully adjust in a single year's time." (p.8). To avoid this critique, we use only the years 1990, 1994, 1998, and 2002. This implies that $F T A_{i j, t-1}$ and $F T A_{i j, t-2}$ are four-year and eight-year lags, respectively; comparable to the 5 year lags in Baier and Bergstrand (2007).

\subsection{Data Description}

Our study covers the period 1990-2002 for a total of 41 trading partners including 40 separate countries and a rest of the world (ROW) aggregate, consisting of 24 additional nations. ${ }^{26}$ None of the countries included in ROW are part of any FTAs with countries in the main sample during the period of investigation. ${ }^{27}$ There are four nations however (Australia, China, Japan, and South Korea), that are treated separately, even though they did not enter any FTA between 1990 and 2002. We use these countries (outsiders), along with the aggregate ROW region, to gauge FTA effects on non-members. The commodities covered include manufacturing production classified according to the United Nations' 2-digit International Standard Industrial Classification (ISIC) Revision $2 .{ }^{28}$

\footnotetext{
${ }^{25}$ In the sensitivity analysis, we split our sample into deep vs. shallow FTAs. We conclude that such differentiation does not affect our main results.

${ }^{26}$ The 40 countries are Argentina, Australia, Austria, Bulgaria, Belgium-Luxembourg, Bolivia, Brazil, Canada, Switzerland, Chile, China, Columbia, Costa Rica, Germany, Denmark, Ecuador, Spain, Finland, France, United Kingdom, Greece, Hungary, Ireland, Iceland, Israel, Italy, Japan, Korea, Rep., Mexico, Morocco, Netherlands, Norway, Poland, Portugal, Romania, Sweden, Tunisia, Turkey, Uruguay, United States. The rest of the world includes Cameroon, Cyprus, Egypt Arab Rep., Hong Kong, Indonesia, India, Iran Islamic Rep., Jordan, Kenya, Kuwait, Sri Lanka, Macao, Malta, Myanmar, Malawi, Malaysia, Niger, Nepal, Philippines, Senegal, Singapore, Trinidad and Tobago, Tanzania, South Africa.

${ }^{27}$ The ROW aggregation is to ease estimation by limiting the very large number of fixed effects.

${ }^{28}$ The nine 2-digit ISIC manufacturing categories are (short labels, used for convenience throughout the paper, are reported in parentheses): 31. Food, Beverages, and Tobacco Products (Food); 32 . Textile,
} 
To estimate gravity and to calculate the indexes of interest, we use industry-level data on bilateral trade flows and output, and we construct expenditures, subject to our structural model, for each trading partner and each commodity class, all measured in thousands of current US dollars for the corresponding year. ${ }^{29}$ In addition, we use data on bilateral distances, contiguous borders, colonial ties, common language, elasticity of substitution, and the presence of regional free trade agreements.

Summary statistics for the main estimation variables (described below) for the first and the last year in the sample as well as data sources and description of all other variables employed in our estimations and analysis are presented in the Supplementary Appendix accompanying this manuscript. ${ }^{30}$ Here, we just describe the two data sources that we use to construct the main explanatory variable, an indicator regressor capturing the presence of FTAs. Most of the data are from the FTA dataset constructed by Baier and Bergstrand (2007), which we update with data on some additional agreements and years from the World Trade Organization (WTO) web site. ${ }^{31}$ Following Baier and Bergstrand (2007), we only consider full FTAs and customs unions that entered into force during the period of investigation, 1990-2002. Table 1 lists the trade agreements included in our sample in chronological order.

Apparel, and Leather Products (Textile); 33. Wood and Wood Products (Wood); 34. Paper and Paper Products (Paper); 35. Chemicals, Petroleum, Coal, Rubber, and Plastic Products (Chemicals); 36. Other Non-metallic Products (Minerals); 37. Basic Metal Industries (Metals); 38. Fabricated Metal Products, Machinery, Equipment (Machinery); 39. Other manufacturing. Inspection of the output data at the 3-digit and 4-digit ISIC level of aggregation reveals that many countries report Equipment production, and especially Scientific Equipment production, under the category Other Manufacturing. Therefore, to avoid inconsistencies, we combine the last two 2-digit categories into one, which we label Machinery.

${ }^{29}$ Baldwin and Taglioni (2006) discuss in length the implications of inappropriate deflation of nominal trade values, which they call "the bronze-medal mistake" in gravity estimations. Their most preferred econometric specification is one with un-deflated trade values, bilateral fixed effects, and time-varying country dummies, which, in addition to accounting for the multilateral resistances in a dynamic setting, will "also eliminate any problems arising from the incorrect deflation of trade." The structural interpretation of the time-varying, country-specific, directional fixed effects (FEs) in our setting is a combination of the multilateral resistance terms and the trading partners output and expenditures. It is easy to see how the FEs would also absorb any deflator indexes, exchange rates, etc. Thus, the realand nominal-trade estimates should be identical.

${ }^{30}$ Descriptive statistics for all variables as well as the data set itself are available by request.

${ }^{31}$ The data from Baier and Bergstrand (2007) can be accessed at the author's web sites http : //www.nd.edu/ jbergstr/ and http: //people.clemson.edu/ sbaier/, respectively. The WTO data is available at http: //www.wto.org/english/tratop /region $_{e} /$ summary $_{e} . x l s$. 


\subsection{Gravity Estimation Results}

Panel PPML estimates of equation (20), obtained with bilateral dummies and timevarying, directional, fixed effects, and accounting for FTA phasing in, are reported in the second panel, labeled 'First Stage', of Table 2. Free trade agreements have positive, and economically and statistically significant impact on bilateral trade flows between member countries. ${ }^{32}$ There is phasing-in of the FTA effects, which are spread relatively evenly over time. The two exceptions are 'Wood and Wood Products' and 'Paper and Paper Products'. These two categories appear to require some time to adjust to the implementation of free trade agreements. ${ }^{33}$

FTA effects on bilateral trade at the commodity level are relatively persistent. For some categories, such as 'Textile, Apparel, and Leather Products' and 'Food, Beverages, and Tobacco Products', there is a large initial effect followed by a gradual decrease. For other categories, such as 'Chemicals, Petroleum, Coal, Rubber, and Plastic Products', the initial FTA effect is relatively small and it increases over time. Finally, there is no clear time trend for 'Basic Metal Products' and 'Fabricated Metal Products, Machinery, and Equipment'. Estimates from row 'L2.FT A' indicate that, for most commodities, the FTA effects are still strong nine years after their entry into force. With one exception, all point estimates of the second four-year lag of the FTA dummy are positive and economically and statistically significant. ${ }^{34}$ The only exception (with positive but small and not statistically significant estimate) is 'Food, Beverages,and Tobacco'. This suggests that FTA effects

\footnotetext{
${ }^{32}$ 'Paper and Paper Products' is the only category for which the initial FTA effect is negative and marginally statistically significant, however very small in magnitude.

${ }^{33}$ Panel estimates obtained without lags (available by request) reveal that 'Wood and Wood Products' and 'Paper and Paper Products' are the only two product categories for which the average FTA treatment effects over the whole period 1990-2002 are not significant. The fact that some average estimates show insignificant, while some of their phasing-in components are significant, reinforces our (and Baier and Bergstrand's, 2007) preferred approach to allow for gradual FTA entering into force.

${ }^{34}$ The fact that L2.FTA is statistically significant in most cases casts doubt on the assumption of strict FTA exogeneity. To test for feedback effects from trade changes to FTA changes, we introduce future values of the FTA dummy in 20. Estimation results, available by request, reveal the following: (i) the future FTA dummy is significant only for Textiles; and, (ii) none of the other FTA estimates change significantly. The textile result is explained by exporters' behavior under the widespread anticipation that textile quotas would be reimposed on the big supplier China once their phase-out mandated by the Uruguay Round agreements was implemented. Small exporters are induced to build market share relative to China, statistically associated with the FTAs that many of them later enter with the US and EU. In combination, (i) and (ii) suggest that our panel treatment has been successful in accounting for FTA endogeneity.
} 
for all or part of the products in this category are short-lived.

Row 'FTA_TOTAL' of Table 2 reports the total FTA effects obtained by summing the values from the first three rows for each product. Standard errors are obtained with the Delta method. All estimates are positive and statistically significant. There is significant variability (within reasonable bounds) in the average treatment FTA effect across different products. The effect is weaker for 'Wood and Wood Products', 'Paper and Paper Products', and 'Non-metallic Products', and stronger for 'Textile, Apparel, and Leather Products', 'Basic Metal Industries', and 'Fabricated Metal Products, Machinery, and Equipment'. These estimates of disaggregated direct FTA effects are in line with findings from related studies that use aggregated data. Varying between 0.286 (for Wood) and 1.291 (for Textiles), our numbers have central tendency comparable to the FTA average treatment effect estimate of 0.76 from Baier and Bergstrand (2007) and to the ATE effect of 0.94 from Rose (2004).

To calculate $t_{i j}$ 's, we adopt a two-step procedure that allows us to simultaneously estimate bilateral trade costs including internal trade costs. ${ }^{35}$ First, we estimate the panel gravity model (20) using the PPML estimator with time-varying, source and destination fixed effects. Next, we re-estimate while imposing the first stage estimated coefficients $\left\{\widehat{\beta}_{i}, \widehat{\eta}_{i t}, \widehat{\theta}_{j t}\right\}$ and replacing the bilateral fixed effects with a regression on the standard

\footnotetext{
${ }^{35}$ One possibility to calculate the $t_{i j}$ 's is to use the estimates of the bilateral fixed effects from specification (20) in combination with the FTA effects:

$$
\hat{t}_{i j}^{1-\sigma}=e^{\hat{\beta}_{i j}+\hat{\beta}_{f t a} F T A_{i j}+\hat{\beta}_{l . f t a} L . F T A_{i j}+\hat{\beta}_{l 2 . f t a} L 2 . F T A_{i j}},
$$

where $\hat{\beta}_{i j}$ is constructed by adding up horizontally the estimates of the country-pair fixed effects. $\hat{\beta}_{f t a}$, $\hat{\beta}_{l . f t a}$, and $\hat{\beta}_{l 2 . f t a}$ are the estimates of the current, lagged, and two-period lagged FTA effects, respectively. This approach cannot obtain internal trade costs $t_{i i}$ 's because perfect collinearity does not allow for separate identification of the fixed effect estimates $\hat{\beta}_{i i}$ 's for individual countries in model (20). Another approach that simultaneously obtains consistent gravity estimates (that can be used to construct bilateral trade costs) and unbiased FTA estimates, is to regress the estimates of the bilateral fixed effects from (20) on the set of standard gravity variables. In analysis available by request, we improve on Cheng and Wall (2005) by using variance weighted least squares to obtain unbiased gravity estimates from the bilateral fixed effects. However, the same critique (not being able to identify internal trade costs separately for each country) applies here as well.
} 
time-invariant gravity covariates:

$$
\begin{aligned}
X_{i j}= & \exp \left[\hat{\beta}_{0}+\hat{\beta}_{1} F T A_{i j, t}+\hat{\beta}_{2} F T A_{i j, t-1}+\hat{\beta}_{3} F T A_{i j, t-2}+\gamma_{1} \ln D I S T_{i j}+\gamma_{2} B R D R_{i j}+\right. \\
& \left.\gamma_{3} L A N G_{i j}+\gamma_{4} C L N Y_{i j}+\sum_{i=5}^{45} \gamma_{i} S M C T R Y_{i j}+\hat{\eta}_{i, t}+\hat{\theta}_{j, t}\right]+\varepsilon_{i j, t} .
\end{aligned}
$$

Then, we use the obtained estimates and actual data on the gravity variables to construct a complete set of power transforms of bilateral trade costs that do not capture the presence of FTAs:

$$
\left(\hat{t}_{i j}^{N O F T A}\right)^{1-\sigma}=e^{\hat{\gamma}_{1} \ln D I S T_{i j}+\hat{\gamma}_{2} B R D R_{i j}+\hat{\gamma}_{3} L A N G_{i j}+\hat{\gamma}_{4} C L N Y_{i j}+\sum_{i=5}^{45} \hat{\gamma}_{i} S M C T R Y_{i j}}
$$

Finally, we add the FTA estimates from (20) to construct a set of bilateral trade costs that do account for FTA presence:

$$
\left(\widehat{t}_{i j}^{F T A}\right)^{1-\sigma}=\left(\widehat{t}_{i j}^{N O F T A}\right)^{1-\sigma} e^{\hat{\beta}_{f t a} F T A_{i j}+\hat{\beta}_{l . f t a} L . F T A_{i j}+\hat{\beta}_{l 2 . f t a} L 2 . F T A_{i j}} .
$$

Provided that the FTA estimates are unbiased (which is ensured by the panel data treatment) and that $\left(\widehat{t}_{i j}^{N O F T A}\right)^{1-\sigma}$ is a good proxy for the time-invariant trade costs (as accepted by the literature), (24) is a valid representation of the direct FTA effects on bilateral trade costs.

Without going into details, we briefly interpret the estimates of (22), which are presented in the top panel, labeled 'Second Stage', of Table 2. ${ }^{36}$ All estimates of the effects of bilateral distance on bilateral trade flows are negative and significant. The variability of the estimates across commodities reflects the influence of value/weight on transportation costs. Common borders facilitate trade. Without exception, the estimates of the coefficients on BRDR are large, positive and significant. The estimated coefficient on LANG is positive and significant for only five of the eight product categories, in contrast to previous findings on aggregated trade. A possible explanation for this result is that over the past quarter-century, manufactures trade has grown between North and South,

\footnotetext{
${ }^{36}$ For a more thorough discussion on a wider set of disaggregated gravity estimates see Anderson and Yotov (2010b).
} 
enhanced by the vertical disintegration of manufacturing, both weakening the influence of common language relative to its effect on aggregate trade found in previous studies. Notably, the largest estimate on LANG is for Paper, which can be explained with the fact that this category includes 'Printing and Publishing Products' whose consumption requires knowledge of a specific language. The role of colonial ties in explaining bilateral trade flows in our analysis is low relative to earlier studies on aggregate data. Six of the eight estimates are positive and significant, marginally so in the case of Minerals. Using more disaggregated data, Anderson and Yotov (2010b) find even weaker evidence of the effects of colonial ties. Home bias in trade is captured by the large, positive, and significant estimates on SMCTRY. These numbers are obtained as weighted averages across all regions in the sample. Individual, country-specific estimates are available by request. The variation of the SMCTRY estimates is intuitive across goods. In particular, the estimates on Food and Paper, which includes 'Printing and Publishing Products', are among the largest, while the estimates on Textiles and Machinery, industries with clear patterns of international specialization, are among the smallest.

Overall, the results from Table 2 are convincing. Aggregate estimations with similar properties have been interpreted as strong evidence in support of gravity theory and used to construct aggregate bilateral trade costs. Similarly, the set of standard gravity covariates and the commodity level estimates derived here can be used to construct a reasonable measure of disaggregated bilateral trade costs.

\section{Real Income Effects of FTAs}

Using the theory of Section 1 and the inferred trade costs of Section 2 we calculate the terms of trade and global efficiency effects of the FTAs that entered into force between 1990 and 2002. The effects on the sellers and the buyers in each country are reported separately and combined into the change in the terms of trade. We also construct and present the global efficiency measures. Finally, we analyze the counter-factual experiment of switching off NAFTA. 


\subsection{Terms of Trade Effects}

Most of the indexes reported here are at the country- and commodity-level and are consistently aggregated from country-commodity pair numbers. The latter are available by request. In addition, to gauge the significance of our indexes, we calculate standard errors by bootstrapping the original FTA estimates. In particular, we first generate 100 sets of bootstrapped PPML gravity estimates of (20), which we use to calculate 100 sets of each of the indexes of interest. Then we calculate standard errors:

$$
\widehat{s e}_{I N D}=\sqrt{\frac{\sum_{i=1}^{n}\left(\widehat{I N D}_{i}-\widehat{I N D}\right)^{2}}{n}}
$$

where: $\widehat{I N D}$ can be any index of interest obtained with the original estimates; $\widehat{I N D}_{i}$ is the corresponding number from the $i^{\text {th }}$ bootstrap sample; and $n$ is the number of bootstrapped sets.

FTA Effects on Sellers. We use factory-gate prices, $p^{*}$ 's, to measure FTA effects on producers, obtained by solving for market clearing prices in (9) subject to normalization (12). Substituting in (9) for the CES price index yields:

$$
\frac{p_{i}^{* k} q_{i}^{k}}{\sum_{i} p_{i}^{* k} q_{i}^{k}}=\sum_{j} \frac{\left(\beta_{i}^{k} p_{i}^{* k} t_{i j}^{k}\right)^{1-\sigma_{k}}}{\sum_{i}\left(\beta_{i}^{k} p_{i}^{* k} t_{i j}^{k}\right)^{1-\sigma_{k}}} \frac{\sum_{k} \phi_{j} p_{j}^{* k} q_{j}^{k}}{\sum_{j, k} \phi_{j} p_{j}^{* k} q_{j}^{k}}, \forall i, k .
$$

(25) consists of NK-K independent equations and, as discussed earlier, the restrictions of separability together with the normalization imply $\mathrm{K}$ additional restrictions on the sectoral price vectors $1=\sum_{i}, p_{i}^{* k} \frac{q_{i}^{k}}{\sum_{i} q_{i}^{k}}, \forall k$, interpreted as maintaining world 'real' resource use in each sector $k$.

We need data on the elasticity of substitution for each goods' class, $\sigma_{k}$, and on the CES share parameters for each country-commodity combination, $\beta_{i}^{k}$. Data on the elasticity of substitution are from Broda et al (2006), ${ }^{37}$ while we construct the CES share parameters

\footnotetext{
${ }^{37}$ See the Data Appendix for description and further details on these numbers. In principle, both the $\sigma_{k}$ 's and the $\beta_{i}^{k}$ 's can be estimated from the structural gravity model. The estimate of the elasticity of substitution arises as the coefficient on tariffs in the gravity model. Due to the lack of reliable sectoral tariff data for the period of investigation however, we choose to use the numbers from Broda et al (2006). The $\beta_{i}^{k}$ 's can also be constructed from gravity, each of them as combination of the exporters' fixed effects. We experimented with those estimates and we obtain initial factory-gate prices that are close to one but
} 
using system (25) evaluated at the initial units choice:

$$
\frac{q_{i}^{k}}{\sum_{i} q_{i}^{k}}=\sum_{j} \frac{\left(\beta_{i}^{k} t_{i j}^{k}\right)^{1-\sigma_{k}}}{\sum_{i}\left(\beta_{i}^{k} t_{i j}^{k}\right)^{1-\sigma_{k}}} \frac{\sum_{k} \phi_{j} q_{j}^{k}}{\sum_{j, k} \phi_{j} q_{j}^{k}}, \forall i, k .
$$

By construction, all $p^{*}$ 's for 1990 are equal to one. The numbers for each of the other three years in our sample (1994, 1998 and 2002) take into account the presence and phasing-in of all free trade agreements that entered into force between 1990 and 2002. We use sectoral output shares as weights to obtain country-level estimates of the factory-gate prices. The numbers in columns 1-3 of Table 3 are percentage changes in prices calculated using the phased-in FTAs for the three years shown. These sellers' price changes measure FTA general equilibrium incidence on the producers in each country.

There is wide variability in the FTA effects on producers. More than one third of the world's producers suffer losses, while the rest enjoy gains. The gains for the winners might be at the expense of the losers. Five of the six biggest losers are the regions that did not enter any FTAs during the 90's. Nevertheless, producer losses are relatively small. Japan, China and S. Korea register the largest losses of more than $0.5 \%$, followed by Chile, ROW and Australia with similar losses. Trade diversion explains why losers lose, while the gainers gains are partly due to the shift from the losers and partly due to a direct benefit of lower trade costs due to the FTA - in effect a transfer from nature. Even though, our sample of outsiders is small, it is tempting to note that producers in the bigger outside regions suffer more.

Interestingly, the next group of countries where producers suffer most from FTAs' are developed nations, including US and Canada. We attribute the negative effects on US and Canadian producers to NAFTA, even though both countries entered other FTAs during the period of investigation as well. Producers in other developed nations suffered minor losses too. The losses for the developed countries are across all sectors but are more pronounced in sectors such as Textile, Apparel, and Leather Products (Textile) and Basic Metal Industries (Metals).

not exactly equal to one. Thus, for general equilibrium consistency we chose the method described in the text. 
The biggest winners from the integration of the 90's are producers from relatively small European and Latin American economies that signed FTAs with large trading partners. From the European economies, Poland and Hungary are leaders with producer gains of $7.3 \%$ and $5.5 \%$, respectively, followed by Bulgaria with $5.3 \%$ increase in producer prices and Romania with 3.9\%. Membership to the Central European Free Trade Agreement (CEFTA), the European Free Trade Association (EFTA) and, consequently, to the European Union (EU) should explain the strong positive effects in these nations. The large gains for these countries come at the expense of other EU members. This is supported by the small losses for the producers in the larger European economies.

Of the Latin American countries, Mexican producers are the biggest winners with $3.3 \%$ increase in their factory-gate prices. Combined with the fact that US and Canada are among the countries with FTA producer losses, this result suggests that NAFTA has benefitted Mexican producers disproportionately, at the expense of producers in the other two partners. The counterfactual exercise of switching off NAFTA (described in Section 3.4) shows that NAFTA is the main reason for the gains to Mexican producers, despite a series of bilateral FTAs as well as agreements between Mexico and most of the other Latin American economies.

FTA Effects on Buyers. FTA effects on buyers in the world are reported in columns 46 of Table 3. Country-level indexes are obtained by aggregating the country-commodity numbers with sectoral-level expenditure shares used as weights. The numbers in each column are percentage changes in the inward multilateral resistances for the base year calculated with and without FTAs. Column ' $\% \Delta 02$ ' captures the total effects over the period 1990-2002 because the 2002 bilateral trade costs (used in the construction of the 2002 IMRs) account for the cumulative, direct FTA impact.

Without exception, buyers in the world benefitted from the integration of the 90's with benefits increasing over time. Importantly, even buyers in nations that did not enter any free trade agreement during the period of investigation enjoy lower prices. ${ }^{38}$ All five such

\footnotetext{
${ }^{38}$ By definition, the IMR values in principle are comparable to price indexes, and in particular their variation across countries might be expected to reflect variation in consumer (or user) price indexes. The IMR's have more variation than CPI's, and we expect that they only loosely track variations in consumer price indexes. A possible explanation is that the inward incidence of trade costs probably
} 
regions in our sample (Australia, China, Japan, South Korea and ROW) register small IMR decreases, though not the smallest in the sample. Another interesting example is Morocco. This country did not enter any FTAs until 2000, yet it enjoyed IMR, though economically insignificant, falls in 1994 and in 1998. The gains increased significantly in 2002 following Morocco's FTA with the European Union in 2000. The intuition is positive spill-over effects: producers in nations that entered FTAs enjoy efficiency gains in distribution that are passed on to all their trading partners, including the ones with whom they have no FTAs.

The variability of the FTA effects on buyers across countries is wide and the pattern makes good intuitive sense for the most part. The biggest FTA winners are relatively small countries that are geographically close to their major markets. Thus the largest FTA gains are for some small European economies including Hungary, Poland and Bulgaria. A partial additional explanation is that liberalization-induced trade cost reductions occurred prior to the FTA because all these nations are founding members of the Central European Free Trade Agreement in 1993, and each of them signed an agreement with, first, the European Free Trade Association, and then with the European Union. Romania follows a similar integration pattern and also registers significant buyer gains.

Buyers in many of the Latin American countries are in the upper tail of the FTA gains' distribution too. Bolivia is the leader with consumer gains of more than $5 \%$. Uruguay and Mexico follow closely with more than $4 \%$ gains. Chile, Ecuador and Argentina also enjoy significant buyer gains. All these nations are members of the Latin American Free Trade Agreement (LAFTA), since 1993. In addition, most of these countries are (founding) members of Mercosur and have FTAs with each other. Finally, NAFTA and series of bilateral FTAs between Mexico and other countries may contribute to the positive effects for this particular country. ${ }^{39}$ Another country that enjoys large buyer gains is Tunisia.

falls on intermediate goods users in a way that does not show up in measured prices. In addition, by construction, the IMRs capture the home bias in preferences that cannot show up in prices.

${ }^{39}$ When interpreting our results, the reader should remember that the equilibrium welfare effects in each country are generated in response to the impact of all FTAs in our sample. While it is probably true that the strongest FTA effect on Mexico comes from NAFTA, the model allows for any other FTA to also influence the welfare of Mexican consumers and producers, even if Mexico is not part of the FTA at all. This is why we observe welfare effects for the countries that did not participate in any free trade agreement initiated between 1990 and 2002. 
The explanation is this nation's FTA with the EU in 1998. Note that in 1994, Tunisia experiences only very small gains from the integration taking place in the rest of the world.

Buyers in most of the developed economies enjoy moderate FTA gains. This is in accordance with the classical trade theory prediction of smaller gains from freer trade for the larger trading partners. Finally, we find that buyers in the five regions that were not involved in any trade agreement initiated between 1990 and 2002 are among the regions in the lower half of the distribution of gains from globalization taking place in the rest of the world.

Terms of Trade Indexes. We combine buyer and seller indexes for each country and year to obtain terms of trade (ToT) numbers and their percentage changes due to FTAs as:

$$
\frac{T_{i}^{F}}{T_{i}^{0}}-1, \forall i
$$

where $T_{i}^{t}$ is defined by (14) evaluated at FTA $(t=F)$ and initial $(t=0)$ prices. $T_{i}$ decomposes into the seller price and buyer price multiplicative components reported separately and multiplicatively combined in the last three columns of Table $3 .{ }^{40}$ The only regions whose terms of trade worsen during the the 90's are the ones that did not enter any FTA. Even though buyers in these regions enjoyed small FTA gains, integration in the rest of the world had a stronger negative impact on sellers. Second, all countries that entered FTAs during the 90's enjoy real income (ToT) gains. This suggests that (i) the direct FTA effects among trading partners dominates the indirect FTA effect from ongoing regional integration in the rest of the world, and (ii) the losses for the producers in larger FTA members are dominated by consumer gains at the national level.

Third, the three nations with the largest ToT improvement during the 90s (of more than 10\%) include Poland, Hungary and Bulgaria. Tunisia is close behind with a ToT improvement of almost 10\%, reflecting its FTA with the EU. The next geographical group of countries that have benefitted enormously from globalization are some Latin American nations, including Mexico, with gains of $7.6 \%$ and Uruguay and Bolivia with gains of

\footnotetext{
${ }^{40}$ The buyers' and sellers' price changes do not sum to the ToT because the changes are discrete.
} 
more than $6 \%$. It should be noted that Mexican producers gain more than producers in Uruguay and Bolivia, but the gains for consumers in the latter two nations are larger. Finally, as expected, large nations benefit less from FTAs. Thus, almost all developed economies are ordered in the lower tail of the distribution of ToT increases. ${ }^{41}$ However, it is important to emphasize that all FTA members enjoy some gains. For example, even though US and Canadian producers suffered losses (probably due to NAFTA) their buyers gain more. In sum, our findings suggest that the integration of the 90's benefitted FTA members while hurting outsiders by an amount too small to be noticeable.

\subsection{Global Efficiency Effects}

To calculate global efficiency indexes (first at the commodity level and then at the world level), first, we obtain aggregates of the outward multilateral resistances (presented and described in the Supplementary Appendix) and of the inward multilateral resistances (discussed above) across all countries. Then, as described in the theoretical section, we construct efficiency measures for each year in our sample. Efficiency estimates are reported in Table 4. The first eight rows of the table report global sectoral indexes and the last row presents the global efficiency measure for world manufacturing in each year. The last column of the table presents the total efficiency changes caused by FTAs during the whole period of investigation.

As can be seen from column '\% $\% 2002$ ', without any exception, all sectors in our sample enjoy statistically significant efficiency gains and there is wide variability across industries. The largest effect is for Textiles, where we estimate an efficiency gain due to FTAs of more than 2 percent. Metals also register a large gain of close to $1 \%$. Food follows with gains of close to $0.7 \%$. The sectors with smallest efficiency gains are Paper and Minerals. A possible explanation for these results is that Paper and Minerals are the sectors with largest SMCTRY estimates, indicating bias toward domestic consumption, while Textiles, for example, is the industry with the lowest SMCTRY estimate. Interestingly however, even though Food had one of the largest estimates of the coefficient on internal trade, we

\footnotetext{
${ }^{41}$ Austria is an exception with total gains of $7.9 \%$, which fall mostly on the consumer side.
} 
find this sector to experience relatively large efficiency gains.

The sectoral level efficiency measures combine to a global efficiency index for the world of $0.62 \%$, which is driven by the large combined share of Food, Textiles and Metals in world manufacturing. It is also interesting to note that for each sector, as well as for global manufacturing, we see that the FTA numbers presented in Table 4 increase over time. In fact we estimate small efficiency losses for Paper in 1994 and 1998 and for Minerals in 1994. In sum, the indexes presented here reveal significant efficiency gains due to the FTAs that entered into force between 1990 and 2002. In addition, we provide evidence that the global efficiency FTA effects are persistent over time in most sectors.

\subsection{Sensitivity Experiments}

Two simplifications in our basic approach seem most problematic, the no rent assumption and the homogeneous FTA effect. Our results are not very sensitive to these simplifications, at least with respect to two simple variations. We also check for the importance of general equilibrium feedback mechanisms by comparing our general equilibrium results with two versions of partial equilibrium measures of terms of trade effects. There are substantial differences in some cases.

Instead of assuming no rents, we alternatively assume that all rents are tariffs and all tariff revenue is fully rebated. We calculate (using (15) with $\tau$ s equal to tariffs) the change in tariff revenue induced by switching on all FTAs in the base year while keeping the base year trade values. ${ }^{42}$ This compares to the change in GDP attributable to the FTAs, $R_{j} \Delta T / T$. The ratio of the former to the latter is reported in the last column of Table 3. In most cases the ratio is small. In the only two cases where the ratio exceeds

\footnotetext{
${ }^{42}$ Four data sources were used to construct bilateral tariffs, needed to calculate tariff revenues. We combined the United Nations Conference on Trade and Development (UNCTAD) Trade Analysis and Information System (TRAINS), the CEPII TradeProd database (This dataset is based on Jon Haveman's UTBC database and CEPII's Market Access Map, MAcMap, database), the World Trade Organization (WTO) Integrated Data Base (IDB), which is available for the years after 1995, and the World Bank's Trade, Production and Protection (TPP) Database, which is based on TRAINS but the authors extend on it by collecting data from national statistical documents and web sites (See Nicita and Olarreaga, 2006). TradeProd tariffs are the base, to which we add bilateral tariffs from TRAINS and IDB. It turns out that bilateral tariff data at the sectoral level needed were available for only about half of countries and commodities in our sample. In the first column of Table 3, we use '*'s to mark the countries for which bilateral tariff data were not available. To substitute for the missing bilateral values, we use average MFN tariffs from TRAINS and IDB.
} 
1, Morocco and Tunisia, the manufacturing base is tiny and there are missing terms of trade gains that presumably accrue to agriculture and other natural resource industries. The conclusions to be drawn are: (i) national gains remain for almost all partners, (ii) some big gains remain (e.g. Poland), (iii) some other big gains are considerably reduced (e.g., Mexico), and (iii) in the only clear instance of a loss, Morocco, gains outside of manufacturing appear likely to overturn the result.

In order to allow for heterogeneous FTA effects on trade, we attempted to distinguish between deep vs. shallow FTAs. ${ }^{43}$ To do this, we relied on the WTO's PTA database, which classifies all PTAs into four groups: Free Trade Agreements, Customs Unions, Economic Integration Agreements (EIAs), and Partial Scope Agreement (PSAs). By definition, all Economic Integration Agreements (EIAs) in our sample are either FTAs or CUs, but not all FTAs or CUs are EIAs. Accordingly, we classify an FTA or a CU as deep if it is also an EIA, and it is classified as shallow otherwise. ${ }^{44}$ We use '*'s to mark the shallow agreements in Table 1.

Disaggregated FTA estimation uses the same econometric techniques as in the main analysis but this time distinguishing between deep and shallow FTAs. Details are available by request. Results show that first, both types of agreements have strong positive effects on bilateral trade. Second, even though the effects of deep vs. shallow FTAs vary within a given commodity category, we were not able to identify any particular pattern. Third, most importantly, there are no statistically significant differences between the total trade effects of shallow vs. deep FTAs for five of the eight categories in our sample. See row "Deep vs. Shallow" of Table 2, where we compare total effects by type of agreement for each commodity in our sample. Furthermore, contrary to what one would expect, we find that the effects of the shallow FTAs are stronger for two (Textile and Paper) of the three goods for which we find statistically different results. Metals is the only category for which the effects of the deep FTAs are stronger. Finally, we do not find any statistically significant difference between the deep and the shallow phasing-in FTA coefficients when

\footnotetext{
${ }^{43}$ It should be noted that, extending on the sample from Baier and Bergstrand (2007), we only cover full FTAs and customs unions (CUs) that entered into force during the period of investigation, 1990-2002.

${ }^{44}$ By construction, our sample does not include PSAs.
} 
we aggregate the data across all manufacturing industries. The difference between the total shallow vs. deep FTA effects in the aggregate sample is 0.026 (0.107), which is both economically and statistically insignificant. Based on these estimates, we do not expect that reproducing all GE results after splitting the sample into deep vs. shallow will lead to any statistically significant changes in our main results. More broadly, the puzzling behavior of Deep vs Shallow indicates that the underlying differences between FTAs are not adequately picked up by this simple dichotomy. Given our ignorance and constrained by limited degrees of freedom, the benchmark uniform FTA specification is preferable.

The importance of the general equilibrium linkages in our approach is revealed by comparison with two partial equilibrium variants. The conditional general equilibrium variant $\mathrm{CE}$ assumes that the $Y$ s and the $E$ s are fixed and uses system (5)-(6) to calculate the new $\Pi_{\mathrm{s}}$ and $P \mathrm{~s}$, and assumes that the sellers' price $p_{i}^{* k}$ moves inversely to $\Pi_{i}^{k}$ in forming the terms of trade changes. The partial equilibrium variant PE maintains fixed Es but replaces the fixed $Y_{i}^{k}$ s with $p_{i}^{* k} q_{i}^{k}$ in solving (5)-(6) and (3) for $\left\{p^{*}, \Pi, P\right\}$. For the many countries where the terms of trade changes are small, the difference between GE, $\mathrm{PE}$ and $\mathrm{CE}$ is also small but large in percentage terms. For the small countries with big terms of trade changes, the percentage differences across methods are small but some of the differences in terms of trade changes are large in economic significance. For example, Poland's terms of trade gain is $1.25 \%$ smaller when calculated in GE as opposed to CE. The details of these calculations are available by request.

\subsection{Counterfactual Experiments}

The framework of this paper is now applied to isolate the effects of a particular free trade agreement (NAFTA) as well as the impact of all FTAs signed by a specific nation (Mexico). ${ }^{45}$ The choice of NAFTA and Mexico, respectively, for counterfactual experiments seems natural as both have been objects of interest for an extensive literature. ${ }^{46}$

\footnotetext{
${ }^{45}$ These FTAs include LAFTA/LAIA (1993) and series of bilateral agreements between Mexico and other partners including Bolivia (1995), Costa Rica (1995), Columbia (1995) (As part of the Group of Three. The third country, Venezuela, is not in the sample), the EU (2000), and Israel (2000).

${ }^{46}$ Our framework can be applied to study series of other interesting counterfactual experiments including global free trade, switch on FTAs for all bilaterals $i \neq j$, or a $1 \%$ fall in trade barriers for all bilaterals $i \neq j$. Another area where our methods can lead to potentially very important contributions is
} 
First, we estimate a hypothetical set of multilateral resistances, factory-gate prices and corresponding FTA ToT effects as if there is no NAFTA (but all other FTAs are still in place). Then, we shut down the rest of the Mexican free trade agreements and we estimate the effects from globalization happening elsewhere in the world.

Table 5 presents our findings. For brevity, we only report the changes in the total welfare (ToT) effects. The numbers in Columns 1 of the table are the indexes from the last column of Table 3, capturing total welfare effects from all FTAs that entered into force during the period of investigation. Column 2 reports welfare effects without NAFTA. The estimates are revealing. First, we find that NAFTA benefits all members, but most of all Mexico. We estimate a staggering fall in the ToT gains for Mexico. NAFTA accounts for more than $82 \%$ percent of the gains from all Mexican FTAs. Canada and the US benefit from NAFTA too, but the real income gains for these countries are significantly smaller, less than $0.1 \%$ each. These results are in accordance with findings from series of computationally intensive CGE models. ${ }^{47}$ Second, our estimates indicate that without NAFTA both Canada and US will actually suffer from integration taking place in the rest of the world during the period of investigation. Note, for example, that the welfare effect for Canada becomes negative after the removal of NAFTA, even though this country has bilateral FTAs with Chile and Bolivia. This suggests that (i) either the direct effects of these two FTAs on Canadian producers are negative and outweigh consumer gains, or (ii) that the effects of globalization elsewhere dominate the direct Canada-Chile and Canada-Bolivia FTA effects.

Third, the hypothetical removal of NAFTA has small impact on other countries too. ${ }^{48}$ According to our estimates, most non-NAFTA members would enjoy small gains if NAFTA were not there. The natural explanation is trade diversion toward the large US

in providing much needed empirical evidence on whether regionalism is a stumbling block or a stepping stone toward global free trade. See the concluding section for more interesting applications.

${ }^{47}$ Our estimate of the welfare gains for Mexico from NAFTA falls comfortably within the range of corresponding CGE indexes. The majority of these numbers are in the 5\%-6\% range, but some studies predict $11 \%$ welfare gains by the year 2000 (see McLeery, 1992) and even $14 \%$ by 2003 (see Klein and Salvatore, 1995). See Brown et al. (1992a) for a concise summary of the findings from leading CGE models regarding the welfare implications of NAFTA.

${ }^{48}$ The small effects on the rest of the world are in accordance with the conclusions from Brown et al. (1992b). 
market, which no longer is served 'freely' by Mexico and Canada. However, we also see some outside nations suffering from the removal of NAFTA. Chile, for example, registers small ToT losses. The explanation might again be trade diversion in the form of increased Mexican presence in the Latin American markets.

In a final experiment, all FTAs in which Mexico took part during the period of investigation are shut down. The resulting changes in the national terms of trade indexes are reported in column 3 of Table 5. Several properties stand out: (a) Mexico is the country that suffers the largest welfare loss. The total FTA welfare effects for this country become negative. If not involved in integration, Mexico would have suffered a minor $(0.06 \%)$ decrease in its terms of trade and manufacturing real GDP due to the FTAs happening elsewhere in the world. (b) All other Latin American countries also experience (often significant) welfare losses due to the removal of the FTA relations that they have with Mexico. ${ }^{49}$ Most of the Latin American countries, however, still enjoy positive FTA welfare effects, probably due to the strong FTA connections among themselves. Costa Rica is the only exception with negative terms of trade changes. (c) Some (more developed) economies in Europe also suffer mild welfare losses. This implies that the direct effects of the removal of the FTA between Mexico and the European Union dominate the indirect (trade diversion) effects from the removal of the rest of the Mexican FTAs (but NAFTA).

\section{Conclusion}

The numbers presented in this paper portray a regional integration process in the 1990's that increased efficiency in each manufacturing sector and in the global economy overall, provided many integrating partners with substantial gains and inflicted small losses on a few countries that did not enter FTAs. The methods developed and the numbers calculated here should be useful for many other purposes.

Our results include a multi-dimensional (country, commodity, and time) data set of producer price, terms of trade and global efficiency indexes that can be used to test

\footnotetext{
${ }^{49}$ Note that some of those countries would have benefitted from the removal of NAFTA. Probably due to trade diversion.
} 
numerous predictions from the theoretical literature on trade liberalization. Preliminary investigation indicates that larger FTA gains are associated with larger number of FTA partners and larger increase in the volume of trade caused by FTAs. In addition, FTA real income gains are inversely related to relative country size and to pre-FTA volumes of trade. These relationships accord with stylized theoretical trade predictions, and open avenues for future empirical work.

The paper offers new methods for analyzing the international externality effects of many policy changes. These can shed light on whether regionalism is a stumbling block or a stepping stone toward global free trade. For example, the effect of many hypothetical FTAs and their sequencing can be calculated to look for stumbling blocks and characterizing their causes. Terms of trade externalities also arise from policies other than FTAs or other trade policies. Future work on domestic policy changes that affect internal trade costs relative to international ones (such as China's massive infrastructure investments), affect supplier costs and volume or buyer costs and volume (such as carbon emissions controls) can readily be examined within this framework. Analysis of intra-national vs. inter-national policies yields important insights (see for example Anderson and Yotov, 2010a).

The simplicity, tractability, and predictive power of the structural gravity model make it an attractive complement to Computable General Equilibrium (CGE) simulation models. The general equilibrium structure of distribution naturally nests inside typical CGE structures, pointing the way toward a better combination of empirical and simulation modeling. 


\section{References}

Anderson, James E. 2008. "Gravity, Productivity and the Pattern of Production and Trade", www2.bc.edu/ SpecificGravity.pdf.

Anderson, James E. 1979. "A theoretical foundation for the gravity equation", American Economic Review 69, 106116.

Anderson, James E. and J. Peter Neary. 2005. Measuring the Restrictiveness of International Trade Policy, Cambridge: MIT Press.

Anderson, James E. and Eric van Wincoop. 2002. "Borders, Trade and Welfare," Brookings Trade Forum 2001, Dani Rodrik and Susan Collins, eds., Washington: Brookings Institution, 2002.

Anderson, James E. and Eric van Wincoop. 2004."Trade Costs", Journal of Economic Literature, 42, 691-751.

Anderson, James E. and Eric van Wincoop. 2003. "Gravity with Gravitas", American Economic Review, 93, 170-92.

Anderson, James E. and Yoto V. Yotov. 2010a. "The Changing Incidence of Geography," American Economic Review, vol. 100(5), pages 2157-86.

Anderson, James E. and Yoto V. Yotov. 2010b. "Specialization: Pro- and Anti-Globalizing, 1990-2002," NBER Working Paper 14423.

Arkolakis, Costas, Arnaud Costinot and Andres Rodriguez-Clare. 2011. "New Trade Modes, Same Old Gains?", American Economic Review, forthcoming.

Baier, Scott L. and Jeffrey H. Bergstrand. 2002. "On the endogeneity of international trade flows and free trade agreements." Manuscript.

Baier, Scott L. and Jeffrey H. Bergstrand. 2004. "Economic determinants of free trade agreements", Journal of International Economics 64, pp. 2963.

Baier, Scott L. and Jeffrey H. Bergstrand. 2007. "Do free trade agreements actually increase members' international trade?," Journal of International Economics, 71(1), 7295.

Baldwin, Richard and Daria Taglioni. 2006. "Gravity for Dummies and Dummies for Gravity Equations," NBER Working Papers 12516. 
Bergstrand, Jeffrey. 1985. "The gravity equation in international trade: some microeconomic foundations and empirical evidence", Review of Economics and Statistics 67, 474481.

Besedes, Tibor and Thomas J. Prusa (2006a), "Product Differentiation and the Duration of US Import Trade", Journal of International Economics, 70(2), 339-58.

Besedes, Tibor and Thomas J. Prusa (2006b), "Ins, Outs and the Duration of Trade", Canadian Journal of Economics, 39 (1), 266-95.

Broda, C., J. Greenfield and D. Weinstein, "From Groundnuts to Globalization: A Structural Estimate of Trade and Growth", NBER Working Paper No. 12512, 2006.

Brown, D.K., 1992. "The Impact of a North American Free Trade Area: Applied General Equilibrium Models", Working Papers 311, University of Michigan.

Brown, D.K. and Deardorff, A.V. and Stern, R.M., 1992. "A North American Free Trade Agreement: Analytical Issues and A Computational Assessment", The World Economy $15,11-30$

Brown, D.K. and Deardorff, A.V. and Stern, R.M., 1992. "North American Integration", Economic Journal, 1992, 102, (415), 1507-18.

Caliendo, Lorenzo and Fernando Parro (2011), "Estimates of the Trade and Welfare Effects of NAFTA", manuscript.

Chang, Won and L. Alan Winters. 2002. "How Regional Blocs Affect Excluded Countries: The Price Effects of MERCOSUR", American Economic Review, 92, 889-902.

Clausing, Kimberley A. 2001. "Trade Creation and Trade Diversion in the Canada-US Free Trade Agreement", Canadian Journal of Economics, 34, 677-96.

Cheng, I.-Hui and Howard J. Wall. 2002. "Controlling for heterogeneity in gravity models of trade", Federal Reserve Bank of St. Louis Working Paper vol. 1999-010C.

Costinot, Arnaud, David Donaldson and Ivana Komunjer (2011), Review of Economic Studies forthcoming.

Deaton, Angus. 1979. "The Distance Function and Consumer Behaviour with Applications to Index Numbers and Optimal Taxation", Review of Economic Studies, 46 (3), 391-405. 
Debreu, Gerard. 1951. "The Coefficient of Resource Utilization", Econometrica, 19, $273-292$.

Eaton, Jonathan and Samuel Kortum (2002), "Technology, Geography and Trade", Econometrica, 70: 1741-1779.

Feenstra, Robert. 2004. Advanced International Trade: Theory and Evidence, Princeton, NJ: Princeton University Press.

Franois Joseph F. and Clinton R. Shiells. 1994. "Modeling Trade Policy: Applied General Equilibrium Assessments of North American Free Trade", Cambridge University Press. Frankel, J.A. 1997. "Regional Trading Blocs", Institute for International Economics, Washington, DC.

Frankel, Jeffrey A., Ernesto Stein and Shang-Jin Wei. 1995. "Trading blocs and the Americas: the natural, the unnatural, and the super-natural", Journal of Development Economics 47, 6195.

Gaulier, G. and S. Zignago. 2008. "BACI: A World Database of International Trade Analysis at the Product Level", Technical report, CEPII Working Paper, Forthcoming. Head, Keith and Thierry Mayer. 2002. "Illusory Border Effects", CEPII Working Paper No. 2002-01.

Head, Keith and Thierry Mayer. 2000. "Non-Europe: The Magnitude and Causes of Market Fragmentation in Europe", Weltwirtschaftliches Archiv 136, 285-314.

Helpman, Elhanan, Marc J. Melitz and Yona Rubinstein. 2008. "Estimating Trade Flows: Trading Partners and Trading Volumes", Harvard University, Quarterly Journal of Economics, 123: 441-487.

Jensen, Paul and Yoto V. Yotov. 2011. "Agriculture, Gravity and Welfare" Manuscript, Drexel University.

Klein, L., Editor , 1991. "Comparative Performance of U.S. Econometric Models", Oxford University Press, New York.

Klein, L.R. and D. Salvatore. 1995. "Welfare Effects of the North American Free Trade Agreement", Journal of Policy Modeling 17, 163-176.

Magee, Chris 2003. "Endogenous preferential trade agreements: an empirical analysis", 
Contributions to Economic Analysis and Policy, 2, Berkeley Electronic Press.

Mayer, T. and R. Paillacar and S. Zignago. 2008. "TradeProd. The CEPII Trade, Production and Bilateral Protection Database: Explanatory Notes", CEPII.

Mayer, T. and S. Zignago. 2006. "Notes on CEPIIs distances measures", CEPII.

Olivero, Maria and Yoto V. Yotov. Forthcoming. "Dynamic Gravity: Theory and Empirical Implications," Canadian Journal of Economics.

Romalis, John. 2007. "NAFTAs and CUSFTAs Impact on North American Trade". Review of Economics and Statistics, 89, 416-35.

Rose, Andrew K. (2004), "Do WTO members have more liberal trade policy? ", Journal of International Economics, 63, 209-235.

Santos Silva, Jorge and Sylvana Tenreyro. 2006. "The Log of Gravity", Review of Economics and Statistics, Vol. 88, No. 4: 641-658.

Trefler, Daniel. 1993. "Trade Liberalization and the Theory of Endogenous Protection: An Econometric Study of U.S. Import Policy," Journal of Political Economy, 101, 138-60. Wolf, Holger. 2000. "Intranational Home Bias in Trade", Review of Economics and Statistics, 82 (4), 555-63.

Wooldridge, J. M. 2002. "Econometric Analysis of Cross Section and Panel Data," MIT Press, Cambridge, MA. 
Table 1: Free Trade Agreements

European Union, or EU (1958): Belgium-Luxembourg, France, Italy, Germany, Netherlands, Denmark (1973), Ireland (1973), United Kingdom (1973), Greece (1981), Portugal (1986),

Spain (1986), Iceland (1994) Austria (1995), Finland (1995), Sweden (1995)

European Free Trade Association, or EFTA (1960): Austria (until 1995), Denmark

(until 1973), Iceland (1970), Finland (1986-1995), Norway, Portugal (until 1986),

Sweden (until 1995), Switzerland, United Kingdom (until 1973)

Latin American Free Trade Agreement/Latin American Integration Agreement, or

LAFTA/LAIA (1993-): Argentina, Bolivia, Brazil, Chile, Ecuador, Mexico, Uruguay

EU-EFTA Agreement/European Economic Area (1973/1994)

*US-Israel (1985)

*US-Canada (1989)

*EFTA-Israel (1993)

Central Europe Free Trade Agreement, or CEFTA (1993): Hungary, Poland, Romania (1997),

Bulgaria (1998)

EFTA-Turkey (1992)

EFTA-Bulgaria (1993)

EFTA-Hungary (1993)

EFTA-Poland (1993)

EFTA-Romania (1993)

Andean Community (1993): Bolivia, Columbia, Ecuador

EU-Hungary (1994)

EU-Poland (1994)

North American Free Trade Agreement, or NAFTA (1994): Canada, Mexico, United States

*Bolivia-Mexico (1995)

Costa Rica-Mexico (1995)

EU-Bulgaria (1995)

EU-Romania (1995)

Columbia-Mexico (1995). As part of the Group of Three. The third country, Venezuela,

is not in the sample.

Mercosur (1991): Argentina, Brazil, Uruguay (formed in 1991 FTA in 1995)

Mercosur-Chile (1996)

Mercosur-Bolivia (1996)

EU-Turkey (1996)

Canada-Chile (1997)

*Canada-Israel (1997)

*Hungary-Turkey (1998)

*Hungary-Israel (1998)

*Israel-Turkey (1998)

*Romania-Turkey (1998)

*Poland-Israel (1998)

*EU-Tunisia (1998)

*Mexico-Chile (1999)

*EU-Israel Agreement (2000)

EU-Mexico (2000)

*EU-Morocco (2000)

*EFTA-Morocco (2000)

*Poland-Turkey (2000)

*Mexico-Israel (2000)

Chile-Costa Rica (2002)

This table lists, in chronological order, all free trade agreements used in the estimations. Only agreements involving the countries in our sample are included. FTAs that entered into force before 1990 are used, when appropriate, to construct the lagged variables of the FTA dummy variable. The latter is constructed from FTAs that entered into force after 1990. '*'s mark the shallow agreements, as defined in the text. 


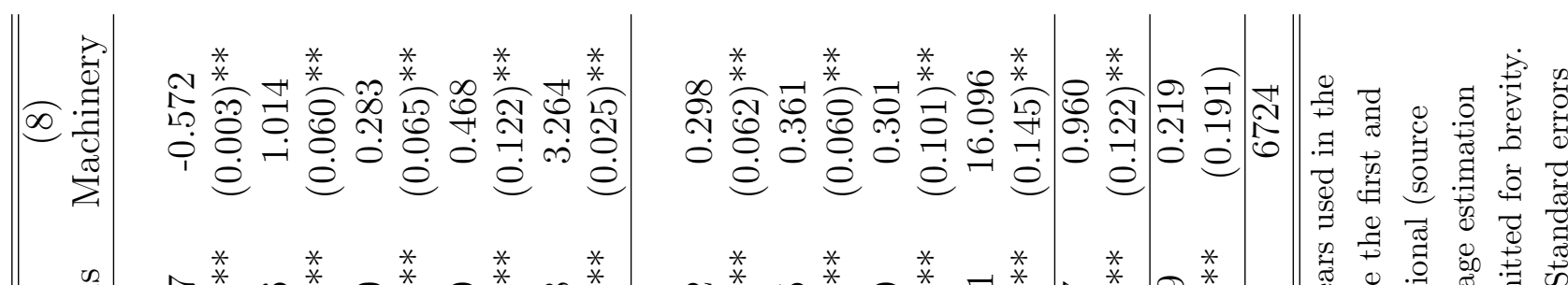

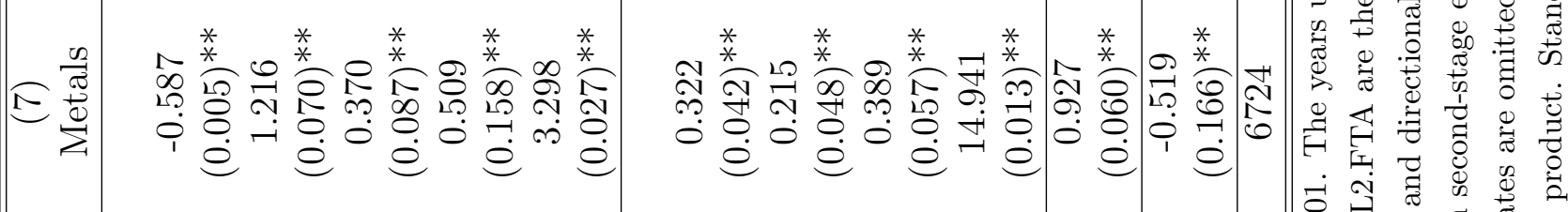

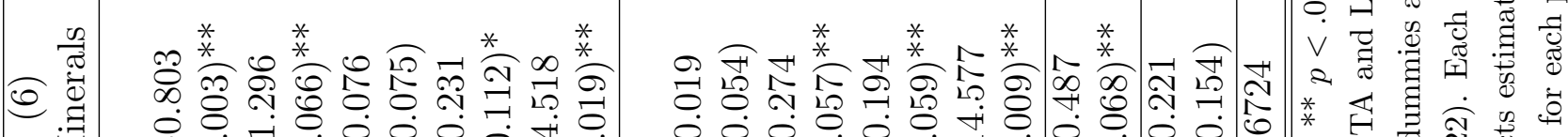
芶 i $\quad$ 过

要

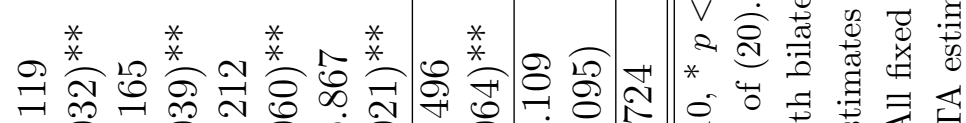

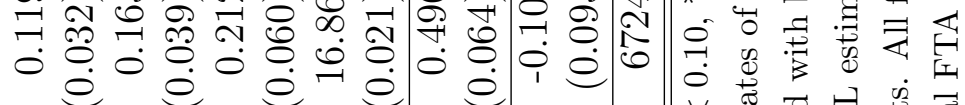

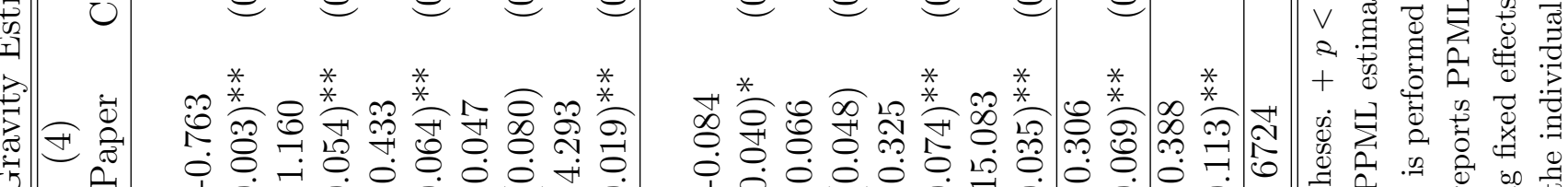

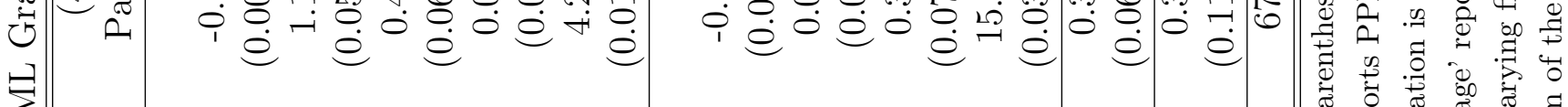

公

剀 i

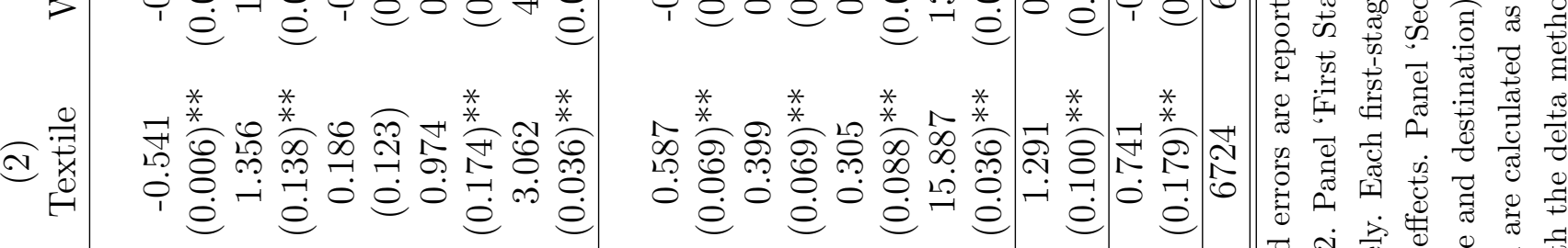

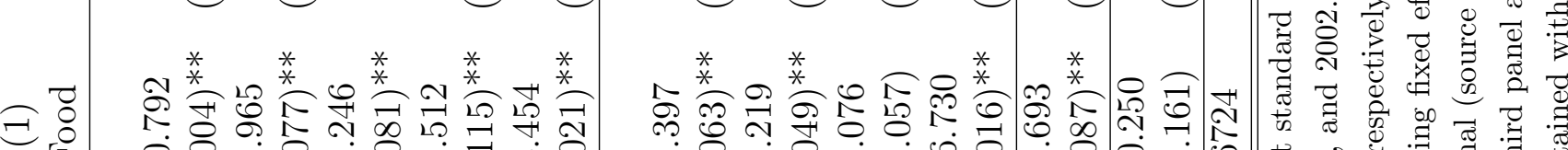

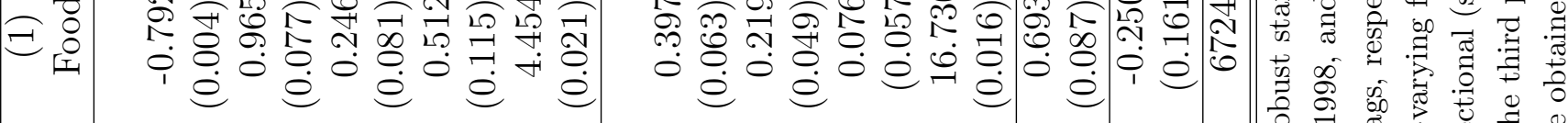

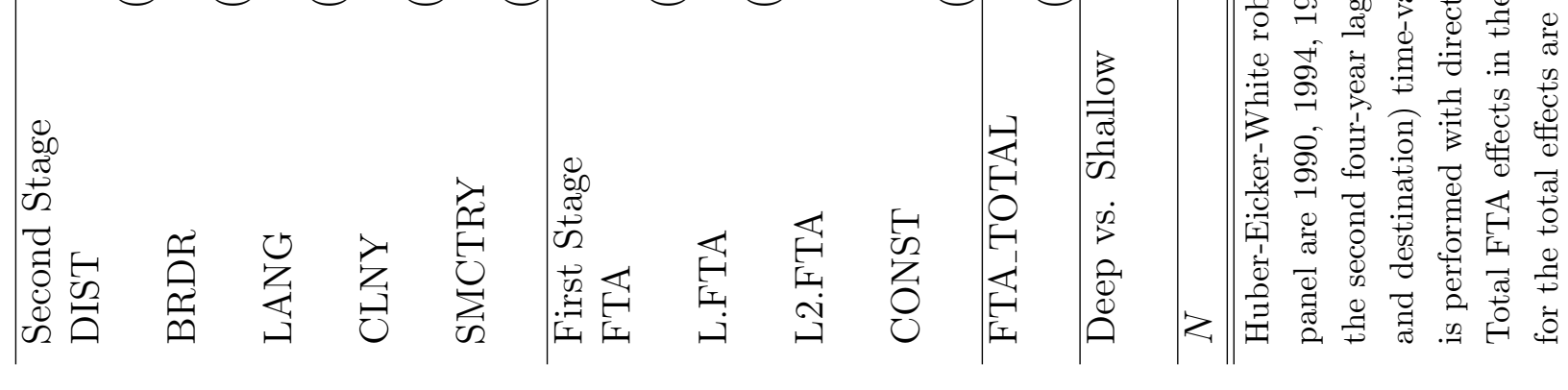


Table 3: General Equilibrium FTA Effects, 1990-2002

\begin{tabular}{|c|c|c|c|c|c|c|c|c|c|c|}
\hline \multirow{3}{*}{ Country Name } & $(1)$ & $(2)$ & $(3)$ & (4) & $(5)$ & (6) & (7) & $(8)$ & (9) & $(10)$ \\
\hline & \multicolumn{3}{|c|}{ Factory-gate Prices } & \multicolumn{3}{|c|}{ IMR's } & \multicolumn{3}{|c|}{ ToT Effects } & $\Delta T R / \Delta R$ \\
\hline & $\% \Delta 94$ & $\% \Delta 98$ & $\% \Delta 02$ & $\% \Delta 94$ & $\% \Delta 98$ & $\% \Delta 02$ & $\% \Delta 94$ & $\% \Delta 98$ & $\% \Delta 02$ & \\
\hline Argentina* & $\begin{array}{c}.272 \\
(.009)\end{array}$ & $\begin{array}{c}.501 \\
(.019)\end{array}$ & $\begin{array}{c}.648 \\
(.025)\end{array}$ & $\begin{array}{l}-.357 \\
(.014)\end{array}$ & $\begin{array}{l}-.787 \\
(.031)\end{array}$ & $\begin{array}{c}-1.405 \\
(.04)\end{array}$ & $\begin{array}{c}.631 \\
(.021)\end{array}$ & $\begin{array}{l}1.296 \\
(.048)\end{array}$ & $\begin{array}{l}2.115 \\
(.062)\end{array}$ & .05 \\
\hline Australia* & $\begin{array}{l}-.037 \\
(.002)\end{array}$ & $\begin{array}{c}-.14 \\
(.005)\end{array}$ & $\begin{array}{l}-.286 \\
(.008)\end{array}$ & $\begin{array}{l}-.023 \\
(.001)\end{array}$ & $\begin{array}{l}-.104 \\
(.004)\end{array}$ & $\begin{array}{l}-.214 \\
(.007)\end{array}$ & $\begin{array}{l}-.012 \\
(.001)\end{array}$ & $\begin{array}{c}-.03 \\
(.001)\end{array}$ & $\begin{array}{l}-.059 \\
(.002)\end{array}$ & 0 \\
\hline Austria & $\begin{array}{c}.049 \\
(.005)\end{array}$ & $\begin{array}{l}1.147 \\
(.043)\end{array}$ & $\begin{array}{l}2.756 \\
(.106)\end{array}$ & $\begin{array}{l}-.211 \\
(.006)\end{array}$ & $\begin{array}{l}-2.348 \\
(.082)\end{array}$ & $\begin{array}{r}-4.676 \\
(.166)\end{array}$ & $\begin{array}{l}.263 \\
(.009)\end{array}$ & $\begin{array}{l}3.604 \\
(.129)\end{array}$ & $\begin{array}{l}7.868 \\
(.296)\end{array}$ & .5 \\
\hline Bulgaria* & $\begin{array}{l}1.152 \\
(.039)\end{array}$ & $\begin{array}{l}3.262 \\
(.113)\end{array}$ & $\begin{array}{l}5.272 \\
(.165)\end{array}$ & $\begin{array}{l}-.802 \\
(.028)\end{array}$ & $\begin{array}{l}-2.669 \\
(.098)\end{array}$ & $\begin{array}{l}-5.209 \\
(.155)\end{array}$ & $\begin{array}{l}2.018 \\
(.069)\end{array}$ & $\begin{array}{l}6.182 \\
(.22)\end{array}$ & $\begin{array}{l}11.079 \\
(.349)\end{array}$ & .1 \\
\hline Blgm-Lxmbrg & $\begin{array}{l}-.041 \\
(.001)\end{array}$ & $\begin{array}{l}.026 \\
(.004)\end{array}$ & $\begin{array}{l}.147 \\
(.008)\end{array}$ & $\begin{array}{l}-.045 \\
(.001)\end{array}$ & $\begin{array}{l}-.122 \\
(.005)\end{array}$ & $\begin{array}{l}-.197 \\
(.007)\end{array}$ & $\begin{array}{l}.004 \\
(0)\end{array}$ & $\begin{array}{l}.133 \\
(.004)\end{array}$ & $\begin{array}{l}.311 \\
(.011)\end{array}$ & .64 \\
\hline Bolivia* & $\begin{array}{l}-.021 \\
(.01)\end{array}$ & $\begin{array}{l}.156 \\
(.019)\end{array}$ & $\begin{array}{l}.565 \\
(.029)\end{array}$ & $\begin{array}{l}-1.767 \\
(.054)\end{array}$ & $\begin{array}{l}-3.431 \\
(.115)\end{array}$ & $\begin{array}{l}-5.195 \\
(.139)\end{array}$ & $\begin{array}{l}2.004 \\
(.064)\end{array}$ & $\begin{array}{l}4.145 \\
(.149)\end{array}$ & $\begin{array}{l}6.743 \\
(.187)\end{array}$ & .31 \\
\hline Brazil & $\begin{array}{c}.096 \\
(.004)\end{array}$ & $\begin{array}{l}.108 \\
(.006)\end{array}$ & $\begin{array}{c}.112 \\
(.009)\end{array}$ & $\begin{array}{l}-.004 \\
(.001)\end{array}$ & $\begin{array}{l}-.077 \\
(.003)\end{array}$ & $\begin{array}{c}-.18 \\
(.007)\end{array}$ & $\begin{array}{l}.111 \\
(.003)\end{array}$ & $\begin{array}{c}.214 \\
(.008)\end{array}$ & $\begin{array}{l}.331 \\
(.01)\end{array}$ & .53 \\
\hline Canada* & $\begin{array}{c}-.004 \\
(0)\end{array}$ & $\begin{array}{l}-.043 \\
(.002)\end{array}$ & $\begin{array}{l}-.126 \\
(.004)\end{array}$ & $\begin{array}{c}-.008 \\
(0)\end{array}$ & $\begin{array}{l}-.076 \\
(.003)\end{array}$ & $\begin{array}{l}-.179 \\
(.006)\end{array}$ & $\begin{array}{l}.003 \\
(0)\end{array}$ & $\begin{array}{l}.026 \\
(.001)\end{array}$ & $\begin{array}{c}.043 \\
(.002)\end{array}$ & .41 \\
\hline Switzerland* & $\begin{array}{l}-.009 \\
(.002)\end{array}$ & $\begin{array}{l}-.025 \\
(.003)\end{array}$ & $\begin{array}{l}-.006 \\
(.006)\end{array}$ & $\begin{array}{l}-.129 \\
(.004)\end{array}$ & $\begin{array}{l}-.177 \\
(.007)\end{array}$ & $\begin{array}{l}-.177 \\
(.006)\end{array}$ & $\begin{array}{l}.119 \\
(.004)\end{array}$ & $\begin{array}{l}.151 \\
(.007)\end{array}$ & $\begin{array}{c}.172 \\
(.009)\end{array}$ & .4 \\
\hline Chile* & $\begin{array}{l}-.284 \\
(.012)\end{array}$ & $\begin{array}{l}-.371 \\
(.016)\end{array}$ & $\begin{array}{l}-.299 \\
(.023)\end{array}$ & $\begin{array}{l}-.945 \\
(.031)\end{array}$ & $\begin{array}{r}-1.974 \\
(.071)\end{array}$ & $\begin{array}{r}-3.049 \\
(.096)\end{array}$ & $\begin{array}{c}.744 \\
(.026)\end{array}$ & $\begin{array}{l}1.761 \\
(.067)\end{array}$ & $\begin{array}{l}3.012 \\
(.092)\end{array}$ & .14 \\
\hline China* & $\begin{array}{c}-.1 \\
(.004)\end{array}$ & $\begin{array}{l}-.335 \\
(.012)\end{array}$ & $\begin{array}{c}-.6 \\
(.019)\end{array}$ & $\begin{array}{l}-.051 \\
(.002)\end{array}$ & $\begin{array}{l}-.193 \\
(.008)\end{array}$ & $\begin{array}{l}-.355 \\
(.012)\end{array}$ & $\begin{array}{l}-.038 \\
(.002)\end{array}$ & $\begin{array}{l}. .108 \\
(.004)\end{array}$ & $\begin{array}{c}-.18 \\
(.006)\end{array}$ & 0 \\
\hline Columbia* & $\begin{array}{c}.019 \\
(.001)\end{array}$ & $\begin{array}{c}.067 \\
(.003)\end{array}$ & $\begin{array}{c}.043 \\
(.005)\end{array}$ & $\begin{array}{l}-.006 \\
(.001)\end{array}$ & $\begin{array}{l}-.066 \\
(.004)\end{array}$ & $\begin{array}{l}-.179 \\
(.008)\end{array}$ & $\begin{array}{c}.024 \\
(.001)\end{array}$ & $\begin{array}{c}.127 \\
(.004)\end{array}$ & $\begin{array}{c}.215 \\
(.008)\end{array}$ & .3 \\
\hline Costa Rica* & $\begin{array}{l}-.027 \\
(.001)\end{array}$ & $\begin{array}{c}.014 \\
(.004)\end{array}$ & $\begin{array}{l}-.015 \\
(.006)\end{array}$ & $\begin{array}{c}.013 \\
(.001)\end{array}$ & $\begin{array}{l}-.037 \\
(.003)\end{array}$ & $\begin{array}{l}-.178 \\
(.008)\end{array}$ & $\begin{array}{l}-.041 \\
(.001)\end{array}$ & $\begin{array}{c}.048 \\
(.003)\end{array}$ & $\begin{array}{c}.00 \\
.162 \\
(.009)\end{array}$ & .6 \\
\hline Germany & $\begin{array}{c}-.01 \\
(.001)\end{array}$ & $\begin{array}{l}.158 \\
(.01)\end{array}$ & $\begin{array}{c}.412 \\
(.018)\end{array}$ & $\begin{array}{c}-.08 \\
(.002)\end{array}$ & $\begin{array}{l}-.146 \\
(.007)\end{array}$ & $\begin{array}{c}-.16 \\
(.007)\end{array}$ & $\begin{array}{c}.065 \\
(.002)\end{array}$ & $\begin{array}{l}.273 \\
(.009)\end{array}$ & $\begin{array}{c}.512 \\
(.016)\end{array}$ & .42 \\
\hline Denmark & $\begin{array}{l}-.008 \\
(.001)\end{array}$ & $\begin{array}{c}.257 \\
(.009)\end{array}$ & $\begin{array}{c}.566 \\
(.021)\end{array}$ & $\begin{array}{l}-.052 \\
(.002)\end{array}$ & $\begin{array}{l}-.235 \\
(.009)\end{array}$ & $\begin{array}{l}-.463 \\
(.017)\end{array}$ & $\begin{array}{l}.041 \\
(.002)\end{array}$ & $\begin{array}{c}.457 \\
(.014)\end{array}$ & $\begin{array}{c}.966 \\
(.033)\end{array}$ & .59 \\
\hline Ecuador* & $\begin{array}{l}-.061 \\
(.009)\end{array}$ & $\begin{array}{l}-.003 \\
(.015)\end{array}$ & $\begin{array}{c}.175 \\
(.025)\end{array}$ & $\begin{array}{c}-.934 \\
(.03)\end{array}$ & $\begin{array}{c}-1.879 \\
(.067)\end{array}$ & $\begin{array}{l}-2.95 \\
(.085)\end{array}$ & $\begin{array}{c}.923 \\
(.032)\end{array}$ & $\begin{array}{l}1.991 \\
(.079)\end{array}$ & $\begin{array}{l}3.342 \\
(.105)\end{array}$ & .19 \\
\hline Spain & $\begin{array}{l}-.045 \\
(.002)\end{array}$ & $\begin{array}{l}-.097 \\
(.005)\end{array}$ & $\begin{array}{l}-.142 \\
(.008)\end{array}$ & $\begin{array}{l}-.05 \\
(.002)\end{array}$ & $\begin{array}{l}-.227 \\
(.009)\end{array}$ & $\begin{array}{l}-.465 \\
(.017)\end{array}$ & $\begin{array}{l}.004 \\
(0)\end{array}$ & $\begin{array}{l}.117 \\
(.004)\end{array}$ & $\begin{array}{l}.291 \\
(.01)\end{array}$ & .31 \\
\hline Finland & $\begin{array}{l}-.006 \\
(.002)\end{array}$ & $\begin{array}{c}.05 \\
(.009)\end{array}$ & $\begin{array}{l}.518 \\
(.028)\end{array}$ & $\begin{array}{l}-.228 \\
(.008)\end{array}$ & $\begin{array}{l}-1.6 \\
(.056)\end{array}$ & $\begin{array}{c}-3.114 \\
(.112)\end{array}$ & $\begin{array}{l}.193 \\
(.006)\end{array}$ & $\begin{array}{l}1.53 \\
(.054)\end{array}$ & $\begin{array}{l}3.452 \\
(.125)\end{array}$ & .35 \\
\hline France & $\begin{array}{l}-.047 \\
(.001)\end{array}$ & $\begin{array}{l}-.044 \\
(.003)\end{array}$ & $\begin{array}{l}-.008 \\
(.004)\end{array}$ & $\begin{array}{l}-.051 \\
(.002)\end{array}$ & $\begin{array}{l}-.131 \\
(.004)\end{array}$ & $\begin{array}{l}-.211 \\
(.007)\end{array}$ & $\begin{array}{l}.004 \\
(0)\end{array}$ & $\begin{array}{c}.084 \\
(.003)\end{array}$ & $\begin{array}{c}.194 \\
(.007)\end{array}$ & .69 \\
\hline UK & $\begin{array}{l}-.045 \\
(.002)\end{array}$ & $\begin{array}{l}-.123 \\
(.004)\end{array}$ & $\begin{array}{l}-.186 \\
(.006)\end{array}$ & $\begin{array}{l}-.056 \\
(.002)\end{array}$ & $\begin{array}{l}-.258 \\
(.008)\end{array}$ & $\begin{array}{l}-.486 \\
(.016)\end{array}$ & $\begin{array}{l}.01 \\
(0)\end{array}$ & $\begin{array}{l}.115 \\
(.004)\end{array}$ & $\begin{array}{l}.259 \\
(.009)\end{array}$ & .57 \\
\hline Greece & $\begin{array}{l}-.079 \\
(.002)\end{array}$ & $\begin{array}{c}.069 \\
(.009)\end{array}$ & $\begin{array}{c}.23 \\
(.02)\end{array}$ & $\begin{array}{l}-.029 \\
(.001)\end{array}$ & $\begin{array}{l}-.772 \\
(.025)\end{array}$ & $\begin{array}{r}-1.687 \\
(.059)\end{array}$ & $\begin{array}{l}-.047 \\
(.002)\end{array}$ & $\begin{array}{c}.908 \\
(.031)\end{array}$ & $\begin{array}{c}2.04 \\
(.079)\end{array}$ & .12 \\
\hline Hungary* & $\begin{array}{l}1.867 \\
(.059)\end{array}$ & $\begin{array}{l}3.567 \\
(.129)\end{array}$ & $\begin{array}{c}5.513 \\
(.16)\end{array}$ & $\begin{array}{r}-1.876 \\
(.074)\end{array}$ & $\begin{array}{r}-4.232 \\
(.164)\end{array}$ & $\begin{array}{r}-6.857 \\
(.217)\end{array}$ & $\begin{array}{l}3.828 \\
(.135)\end{array}$ & $\begin{array}{l}8.166 \\
(.314)\end{array}$ & $\begin{array}{c}13.192 \\
(.425)\end{array}$ & .19 \\
\hline Ireland & $\begin{array}{l}-.025 \\
(.001)\end{array}$ & $\begin{array}{c}.043 \\
(.003)\end{array}$ & $\begin{array}{c}.144 \\
(.008)\end{array}$ & $\begin{array}{l}-.053 \\
(.002)\end{array}$ & $\begin{array}{l}-.283 \\
(.01)\end{array}$ & $\begin{array}{l}-.58 \\
(.02)\end{array}$ & $\begin{array}{c}.027 \\
(.001)\end{array}$ & $\begin{array}{l}.311 \\
(.01)\end{array}$ & $\begin{array}{c}.691 \\
(.023)\end{array}$ & .2 \\
\hline Iceland* & $\begin{array}{l}.065 \\
(.002)\end{array}$ & $\begin{array}{c}.061 \\
(.004)\end{array}$ & $\begin{array}{l}.102 \\
(.005)\end{array}$ & $\begin{array}{l}-.244 \\
(.009)\end{array}$ & $\begin{array}{l}-.508 \\
(.02)\end{array}$ & $\begin{array}{c}-.8 \\
(.025)\end{array}$ & $\begin{array}{l}.31 \\
(.01)\end{array}$ & $\begin{array}{l}.572 \\
(.022)\end{array}$ & $\begin{array}{c}.91 \\
(.027)\end{array}$ & .04 \\
\hline Israel $^{*}$ & $\begin{array}{l}.204 \\
(.01)\end{array}$ & $\begin{array}{c}.304 \\
(.016)\end{array}$ & $\begin{array}{c}1.14 \\
(.046)\end{array}$ & $\begin{array}{l}-.388 \\
(.012)\end{array}$ & $\begin{array}{l}-.781 \\
(.028)\end{array}$ & $\begin{array}{l}-2.435 \\
(.063)\end{array}$ & $\begin{array}{l}.608 \\
(.022)\end{array}$ & $\begin{array}{l}1.104 \\
(.043)\end{array}$ & $\begin{array}{l}3.684 \\
(.111)\end{array}$ & .49 \\
\hline Italy & $\begin{array}{l}-.081 \\
(.003)\end{array}$ & $\begin{array}{l}-.08 \\
(.004)\end{array}$ & $\begin{array}{l}-.045 \\
(.006)\end{array}$ & $\begin{array}{l}-.073 \\
(.002)\end{array}$ & $\begin{array}{l}-.239 \\
(.007)\end{array}$ & $\begin{array}{l}-.416 \\
(.013)\end{array}$ & $\begin{array}{l}-.005 \\
(.001)\end{array}$ & $\begin{array}{l}.168 \\
(.006)\end{array}$ & $\begin{array}{c}.383 \\
(.014)\end{array}$ & .39 \\
\hline
\end{tabular}

Continued 
Table 3 - continued from previous page

\begin{tabular}{|c|c|c|c|c|c|c|c|c|c|c|}
\hline \multirow{3}{*}{ Country Name } & (1) & (2) & (3) & (4) & (5) & (6) & (7) & (8) & (9) & (10) \\
\hline & \multicolumn{3}{|c|}{ Factory-gate Prices } & \multicolumn{3}{|c|}{ IMR's } & \multicolumn{3}{|c|}{ ToT Effects } & $\Delta T R / \Delta R$ \\
\hline & $\% \Delta 94$ & $\% \Delta 98$ & $\% \Delta 02$ & $\% \Delta 94$ & $\% \Delta 98$ & $\% \Delta 02$ & $\% \Delta 94$ & $\% \Delta 98$ & $\% \Delta 02$ & \\
\hline Japan & $\begin{array}{l}-.065 \\
(.004)\end{array}$ & $\begin{array}{l}-.266 \\
(.012)\end{array}$ & $\begin{array}{r}-.527 \\
(.02)\end{array}$ & $\begin{array}{l}-.042 \\
(.003)\end{array}$ & $\begin{array}{l}.183 \\
(.009)\end{array}$ & $\begin{array}{c}-.377 \\
(.014)\end{array}$ & $\begin{array}{c}.01 \\
(.001)\end{array}$ & $\begin{array}{l}-.042 \\
(.002)\end{array}$ & $\begin{array}{l}-.074 \\
(.003)\end{array}$ & 0 \\
\hline S. Korea & $\begin{array}{l}-.071 \\
(.003)\end{array}$ & $\begin{array}{l}-.267 \\
(.011)\end{array}$ & $\begin{array}{l}-.509 \\
(.017)\end{array}$ & $\begin{array}{l}-.035 \\
(.002)\end{array}$ & $\begin{array}{l}-.158 \\
(.007)\end{array}$ & $\begin{array}{c}-.31 \\
(.012)\end{array}$ & $\begin{array}{l}-.022 \\
(.001)\end{array}$ & $\begin{array}{c}-.07 \\
(.002)\end{array}$ & $\begin{array}{l}-.125 \\
(.004)\end{array}$ & 0 \\
\hline Morocco* & $\begin{array}{l}-.067 \\
(.002)\end{array}$ & $\begin{array}{l}-.242 \\
(.008)\end{array}$ & $\begin{array}{c}.888 \\
(.042)\end{array}$ & $\begin{array}{c}-.003 \\
(0)\end{array}$ & $\begin{array}{l}-.009 \\
(.001)\end{array}$ & $\begin{array}{c}-2.213 \\
(.079)\end{array}$ & $\begin{array}{l}-.064 \\
(.002)\end{array}$ & $\begin{array}{l}-.233 \\
(.007)\end{array}$ & $\begin{array}{l}3.206 \\
(.117)\end{array}$ & 2.46 \\
\hline Mexico* & $\begin{array}{l}1.203 \\
(.038)\end{array}$ & $\begin{array}{l}2.237 \\
(.072)\end{array}$ & $\begin{array}{l}3.319 \\
(.093)\end{array}$ & $\begin{array}{l}-.571 \\
(.033)\end{array}$ & $\begin{array}{r}-1.765 \\
(.081)\end{array}$ & $\begin{array}{c}-4.322 \\
(.134)\end{array}$ & $\begin{array}{l}1.712 \\
(.057)\end{array}$ & $\begin{array}{c}3.91 \\
(.146)\end{array}$ & $\begin{array}{l}7.593 \\
(.22)\end{array}$ & .72 \\
\hline Netherlands & $\begin{array}{c}-.02 \\
(.001)\end{array}$ & $\begin{array}{l}.124 \\
(.005)\end{array}$ & $\begin{array}{c}.316 \\
(.012)\end{array}$ & $\begin{array}{l}-.045 \\
(.002)\end{array}$ & $\begin{array}{l}-.135 \\
(.005)\end{array}$ & $\begin{array}{l}-.235 \\
(.009)\end{array}$ & $\begin{array}{c}.022 \\
(.001)\end{array}$ & $\begin{array}{l}.228 \\
(.007)\end{array}$ & $\begin{array}{c}.489 \\
(.016)\end{array}$ & .56 \\
\hline Norway* & $\begin{array}{c}.001 \\
(.001)\end{array}$ & $\begin{array}{l}-.072 \\
(.003)\end{array}$ & $\begin{array}{c}-.06 \\
(.008)\end{array}$ & $\begin{array}{l}-.227 \\
(.008)\end{array}$ & $\begin{array}{l}-.472 \\
(.018)\end{array}$ & $\begin{array}{l}-.662 \\
(.022)\end{array}$ & $\begin{array}{c}.205 \\
(.007)\end{array}$ & $\begin{array}{c}.358 \\
(.015)\end{array}$ & $\begin{array}{c}.539 \\
(.017)\end{array}$ & .05 \\
\hline Poland* & $\begin{array}{l}2.396 \\
(.077)\end{array}$ & $\begin{array}{l}4.666 \\
(.167)\end{array}$ & $\begin{array}{c}7.31 \\
(.207)\end{array}$ & $\begin{array}{r}-2.102 \\
(.086)\end{array}$ & $\begin{array}{r}-4.766 \\
(.186)\end{array}$ & $\begin{array}{r}-7.701 \\
(.246)\end{array}$ & $\begin{array}{l}4.586 \\
(.165)\end{array}$ & $\begin{array}{l}9.908 \\
(.383)\end{array}$ & $\begin{array}{c}16.112 \\
(.521)\end{array}$ & .09 \\
\hline Portugal & $\begin{array}{l}-.071 \\
(.002)\end{array}$ & $\begin{array}{l}-.122 \\
(.005)\end{array}$ & $\begin{array}{c}-.15 \\
(.005)\end{array}$ & $\begin{array}{c}-.06 \\
(.002)\end{array}$ & $\begin{array}{c}-.31 \\
(.011)\end{array}$ & $\begin{array}{l}-.642 \\
(.023)\end{array}$ & $\begin{array}{l}-.009 \\
(.001)\end{array}$ & $\begin{array}{c}.195 \\
(.008)\end{array}$ & $\begin{array}{c}.498 \\
(.019)\end{array}$ & .25 \\
\hline Romania* & $\begin{array}{c}.698 \\
(.022)\end{array}$ & $\begin{array}{l}2.297 \\
(.075)\end{array}$ & $\begin{array}{l}3.851 \\
(.12)\end{array}$ & $\begin{array}{l}-.213 \\
(.011)\end{array}$ & $\begin{array}{l}-1.31 \\
(.057)\end{array}$ & $\begin{array}{c}-3.068 \\
(.107)\end{array}$ & $\begin{array}{c}.907 \\
(.031)\end{array}$ & $\begin{array}{l}3.614 \\
(.128)\end{array}$ & $\begin{array}{l}6.971 \\
(.232)\end{array}$ & .13 \\
\hline ROW & $\begin{array}{l}-.045 \\
(.002)\end{array}$ & $\begin{array}{l}-.156 \\
(.006)\end{array}$ & $\begin{array}{r}-.266 \\
(.01)\end{array}$ & $\begin{array}{l}-.014 \\
(.001)\end{array}$ & $\begin{array}{l}-.067 \\
(.003)\end{array}$ & $\begin{array}{c}-.11 \\
(.005)\end{array}$ & $\begin{array}{l}-.024 \\
(.001)\end{array}$ & $\begin{array}{l}-.067 \\
(.002)\end{array}$ & $\begin{array}{l}-.115 \\
(.004)\end{array}$ & 0 \\
\hline Sweden & $\begin{array}{c}0 \\
(.003)\end{array}$ & $\begin{array}{c}.053 \\
(.014)\end{array}$ & $\begin{array}{c}.522 \\
(.031)\end{array}$ & $\begin{array}{l}-.231 \\
(.008)\end{array}$ & $\begin{array}{r}-1.706 \\
(.054)\end{array}$ & $\begin{array}{r}-3.222 \\
(.111)\end{array}$ & $\begin{array}{c}.202 \\
(.007)\end{array}$ & $\begin{array}{l}1.643 \\
(.057)\end{array}$ & $\begin{array}{c}3.586 \\
(.13)\end{array}$ & .45 \\
\hline Tunisia & $\begin{array}{c}-.09 \\
(.003)\end{array}$ & $\begin{array}{l}1.625 \\
(.062)\end{array}$ & $\begin{array}{c}3.49 \\
(.146)\end{array}$ & $\begin{array}{c}.008 \\
(0)\end{array}$ & $\begin{array}{c}-2.415 \\
(.089)\end{array}$ & $\begin{array}{c}-5.223 \\
(.191)\end{array}$ & $\begin{array}{l}-.099 \\
(.003)\end{array}$ & $\begin{array}{l}4.211 \\
(.147)\end{array}$ & $\begin{array}{l}9.267 \\
(.356)\end{array}$ & 1.09 \\
\hline Turkey* & $\begin{array}{c}.206 \\
(.013)\end{array}$ & $\begin{array}{l}1.065 \\
(.049)\end{array}$ & $\begin{array}{l}2.014 \\
(.085)\end{array}$ & $\begin{array}{l}-.461 \\
(.018)\end{array}$ & $\begin{array}{r}-1.961 \\
(.072)\end{array}$ & $\begin{array}{r}-3.889 \\
(.121)\end{array}$ & $\begin{array}{c}.678 \\
(.024)\end{array}$ & $\begin{array}{c}3.04 \\
(.108)\end{array}$ & $\begin{array}{l}5.898 \\
(.195)\end{array}$ & .16 \\
\hline Uruguay* & $\begin{array}{c}.617 \\
(.023)\end{array}$ & $\begin{array}{l}1.327 \\
(.056)\end{array}$ & $\begin{array}{l}2.093 \\
(.072)\end{array}$ & $\begin{array}{c}-1.393 \\
(.045)\end{array}$ & $\begin{array}{c}-2.819 \\
(.098)\end{array}$ & $\begin{array}{c}-4.438 \\
(.124)\end{array}$ & $\begin{array}{c}2.25 \\
(.074)\end{array}$ & $\begin{array}{l}4.663 \\
(.173)\end{array}$ & $\begin{array}{l}7.451 \\
(.22)\end{array}$ & .08 \\
\hline USA & $\begin{array}{c}.004 \\
(.001)\end{array}$ & $\begin{array}{l}-.011 \\
(.001)\end{array}$ & $\begin{array}{l}-.087 \\
(.005)\end{array}$ & $\begin{array}{l}-.022 \\
(.001)\end{array}$ & $\begin{array}{l}-.062 \\
(.002)\end{array}$ & $\begin{array}{l}-.158 \\
(.006)\end{array}$ & $\begin{array}{c}.019 \\
(.001)\end{array}$ & $\begin{array}{c}.039 \\
(.002)\end{array}$ & $\begin{array}{c}.054 \\
(.002)\end{array}$ & .52 \\
\hline
\end{tabular}

Notes: This table reports percentage changes in factory-gate prices, inward multilateral resistances and ToT indexes for each country and year in our sample. Country-level factory-gate prices are constructed as weighted averages across all country-commodity indexes with output shares used as weights. IMR's are aggregated from the country-commodity numbers with expenditure shares used as weights. ToT's are calculated as the difference between the corresponding effects on producers (the factory-gate prices) and consumers (IMR's). Standard errors are obtained as described in the text. The last columns reports the ratio of potential tariff revenue losses to output gains due to FTAs. See text for further details. 
Table 4: Global Efficiency Indexes, 1990-2002

\begin{tabular}{|l|c|c|c|}
\hline \hline Country Name & $\% \Delta 1994$ & $\% \Delta 1998$ & $\% \Delta 2002$ \\
\hline Food & .18 & .457 & .683 \\
Textile & $(0.001)$ & $(0.001)$ & $(0.001)$ \\
& .395 & 1.24 & 2.056 \\
Wood & $(0.001)$ & $(.002)$ & $(0.004)$ \\
Paper & .001 & .126 & .548 \\
& $(0.001)$ & $(0.001)$ & $(0.001)$ \\
Chemicals & -.003 & -.001 & .164 \\
& $(0.001)$ & $(0.001)$ & $(0.001)$ \\
Minerals & .07 & .252 & .524 \\
& $(0.001)$ & $(0.001)$ & $(0.001)$ \\
Metals & -.017 & .011 & .113 \\
& $(0.001)$ & $(0.001)$ & $(0.001)$ \\
Machinery & .217 & .524 & .967 \\
& $(0.001)$ & $(0.001)$ & $(0.001)$ \\
Mnfctrng & .054 & .229 & .478 \\
& $(0.001)$ & $(0.001)$ & $(0.001)$ \\
\hline \hline
\end{tabular}

Notes: This table reports global efficiency measures for each sector and aggregate manufacturing numbers obtained from the country-commodity OMR's. See text for procedures used to obtain the efficiency indexes and the standard errors accompanying them. 
Table 5: Counterfactual FTA Experiments

\begin{tabular}{|c|c|c|c|}
\hline & (1) & $(2)$ & $(3)$ \\
\hline Country Name & All FTAs & No NAFTA & No FTAs Mexico \\
\hline Argentina & $\begin{array}{l}2.115 \\
(.062)\end{array}$ & $\begin{array}{c}2.12 \\
(.053)\end{array}$ & $\begin{array}{l}1.955 \\
(.046)\end{array}$ \\
\hline Australia & $\begin{array}{l}-.059 \\
(.002)\end{array}$ & $\begin{array}{l}-.049 \\
(.002)\end{array}$ & $\begin{array}{l}-.045 \\
(.006)\end{array}$ \\
\hline Austria & $\begin{array}{l}7.868 \\
(.296)\end{array}$ & $\begin{array}{l}7.874 \\
(.266)\end{array}$ & $\begin{array}{l}7.87 \\
(.261)\end{array}$ \\
\hline Bulgaria & $\begin{array}{c}11.079 \\
(.349)\end{array}$ & $\begin{array}{c}11.088 \\
(.32)\end{array}$ & $\begin{array}{c}11.074 \\
(.32)\end{array}$ \\
\hline Blgm-Lxmbrg & $\begin{array}{l}.311 \\
(.011)\end{array}$ & $\begin{array}{l}.315 \\
(.006)\end{array}$ & $\begin{array}{l}.308 \\
(.011)\end{array}$ \\
\hline Bolivia & $\begin{array}{l}6.743 \\
(.187)\end{array}$ & $\begin{array}{l}6.741 \\
(.166)\end{array}$ & $\begin{array}{l}6.457 \\
(.151)\end{array}$ \\
\hline Brazil & $\begin{array}{l}.331 \\
(.01)\end{array}$ & $\begin{array}{l}.337 \\
(.009)\end{array}$ & $\begin{array}{l}.251 \\
(.009)\end{array}$ \\
\hline Canada & $\begin{array}{l}.043 \\
(.002)\end{array}$ & $\begin{array}{l}-.007 \\
(.003)\end{array}$ & $\begin{array}{l}-.003 \\
(.007)\end{array}$ \\
\hline Switzerland & $\begin{array}{l}.172 \\
(.009)\end{array}$ & $\begin{array}{l}.178 \\
(.019)\end{array}$ & $\begin{array}{l}.174 \\
(.027)\end{array}$ \\
\hline Chile & $\begin{array}{l}3.012 \\
(.092)\end{array}$ & $\begin{array}{l}2.998 \\
(.083)\end{array}$ & $\begin{array}{c}2.77 \\
(.071)\end{array}$ \\
\hline China & $\begin{array}{c}-.18 \\
(.006)\end{array}$ & $\begin{array}{l}-.171 \\
(.01)\end{array}$ & $\begin{array}{l}-.155 \\
(.011)\end{array}$ \\
\hline Columbia & $\begin{array}{l}.215 \\
(.008)\end{array}$ & $\begin{array}{c}.228 \\
(.008)\end{array}$ & $\begin{array}{l}.054 \\
(.02)\end{array}$ \\
\hline Costa Rica & $\begin{array}{l}.162 \\
(.009)\end{array}$ & $\begin{array}{l}.184 \\
(.005)\end{array}$ & $\begin{array}{l}-.115 \\
(.023)\end{array}$ \\
\hline Germany & $\begin{array}{l}.512 \\
(.016)\end{array}$ & $\begin{array}{l}.518 \\
(.009)\end{array}$ & $\begin{array}{l}.514 \\
(.009)\end{array}$ \\
\hline Denmark & $\begin{array}{c}.966 \\
(.033)\end{array}$ & $\begin{array}{c}.964 \\
(.016)\end{array}$ & $\begin{array}{c}.954 \\
(.016)\end{array}$ \\
\hline Ecuador & $\begin{array}{l}3.342 \\
(.105)\end{array}$ & $\begin{array}{l}3.375 \\
(.099)\end{array}$ & $\begin{array}{l}2.994 \\
(.08)\end{array}$ \\
\hline Spain & $\begin{array}{l}.291 \\
(.01)\end{array}$ & $\begin{array}{c}.297 \\
(.005)\end{array}$ & $\begin{array}{c}.281 \\
(.006)\end{array}$ \\
\hline Finland & $\begin{array}{l}3.452 \\
(.125)\end{array}$ & $\begin{array}{l}3.456 \\
(.117)\end{array}$ & $\begin{array}{c}3.45 \\
(.114)\end{array}$ \\
\hline France & $\begin{array}{l}.194 \\
(.007)\end{array}$ & $\begin{array}{l}.193 \\
(.01)\end{array}$ & $\begin{array}{l}.193 \\
(.01)\end{array}$ \\
\hline UK & $\begin{array}{l}.259 \\
(.009)\end{array}$ & $\begin{array}{l}.264 \\
(.011)\end{array}$ & $\begin{array}{l}.259 \\
(.008)\end{array}$ \\
\hline Greece & $\begin{array}{l}2.04 \\
(.079)\end{array}$ & $\begin{array}{l}2.043 \\
(.062)\end{array}$ & $\begin{array}{l}2.028 \\
(.06)\end{array}$ \\
\hline Hungary & $\begin{array}{l}13.192 \\
(.425)\end{array}$ & $\begin{array}{c}13.195 \\
(.41)\end{array}$ & $\begin{array}{l}13.185 \\
(.408)\end{array}$ \\
\hline Ireland & $\begin{array}{l}.691 \\
(.023)\end{array}$ & $\begin{array}{l}.696 \\
(.021)\end{array}$ & $\begin{array}{l}.679 \\
(.014)\end{array}$ \\
\hline Iceland & $\begin{array}{c}.91 \\
(.027)\end{array}$ & $\begin{array}{l}.914 \\
(.022)\end{array}$ & $\begin{array}{l}.88 \\
(.024)\end{array}$ \\
\hline Israel & $\begin{array}{l}3.684 \\
(.111)\end{array}$ & $\begin{array}{l}3.696 \\
(.115)\end{array}$ & $\begin{array}{l}3.682 \\
(.109)\end{array}$ \\
\hline Italy & $\begin{array}{l}.383 \\
(.014)\end{array}$ & $\begin{array}{l}.387 \\
(.007)\end{array}$ & $\begin{array}{l}.385 \\
(.007)\end{array}$ \\
\hline Japan & -.074 & -.067 & -.064 \\
\hline
\end{tabular}

Continued 
Table 5 - continued from previous page

\begin{tabular}{|c|c|c|c|}
\hline & (1) & $(2)$ & $(3)$ \\
\hline \multirow[t]{2}{*}{ Country Name } & All FTAs & No NAFTA & No FTAs Mexico \\
\hline & $(.003)$ & $(.004)$ & $(.004)$ \\
\hline \multirow[t]{2}{*}{ S. Korea } & -.125 & -.113 & -.105 \\
\hline & $(.004)$ & $(.002)$ & $(.002)$ \\
\hline \multirow[t]{2}{*}{ Morocco } & 3.206 & 3.214 & 3.199 \\
\hline & $(.117)$ & $(.122)$ & $(.114)$ \\
\hline \multirow[t]{2}{*}{ Mexico } & 7.593 & 1.368 & -.06 \\
\hline & $(.22)$ & $(.032)$ & $(.025)$ \\
\hline \multirow[t]{2}{*}{ Netherlands } & .489 & .489 & .483 \\
\hline & $(.016)$ & $(.013)$ & $(.013)$ \\
\hline \multirow[t]{2}{*}{ Norway } & .539 & .547 & .534 \\
\hline & $(.017)$ & $(.017)$ & $(.019)$ \\
\hline \multirow[t]{2}{*}{ Poland } & 16.112 & 16.117 & 16.111 \\
\hline & $(.521)$ & $(.498)$ & $(.503)$ \\
\hline \multirow[t]{2}{*}{ Portugal } & .498 & .511 & .495 \\
\hline & $(.019)$ & $(.01)$ & $(.011)$ \\
\hline \multirow[t]{2}{*}{ Romania } & 6.971 & 6.978 & 6.966 \\
\hline & $(.232)$ & $(.218)$ & $(.214)$ \\
\hline \multirow[t]{2}{*}{ ROW } & -.115 & -.111 & -.103 \\
\hline & $(.004)$ & $(.007)$ & $(.008)$ \\
\hline \multirow[t]{2}{*}{ Sweden } & 3.586 & 3.596 & 3.588 \\
\hline & $(.13)$ & $(.123)$ & $(.12)$ \\
\hline \multirow[t]{2}{*}{ Tunisia } & 9.267 & 9.273 & 9.257 \\
\hline & $(.356)$ & $(.368)$ & $(.355)$ \\
\hline \multirow[t]{2}{*}{ Turkey } & 5.898 & 5.905 & 5.896 \\
\hline & $(.195)$ & $(.184)$ & $(.182)$ \\
\hline \multirow[t]{2}{*}{ Uruguay } & 7.451 & 7.471 & 7.196 \\
\hline & $(.22)$ & $(.199)$ & $(.184)$ \\
\hline \multirow[t]{2}{*}{ USA } & .054 & -.024 & -.019 \\
\hline & $(.002)$ & $(.001)$ & $(.002)$ \\
\hline
\end{tabular}

Notes: The indexes in this table are aggregate country-level ToT effects. The numbers in column 1 account for the presence of all FTAs. The numbers in column 2 are constructed as if there was no NAFTA. The indexes in the third column are calculated as if Mexico was not involved in any FTA during the 90 s. Standard errors are obtained as described in the text. 